\title{
Description and evaluation of GMXe: a new aerosol submodel for global simulations (v1)
}

\author{
K. J. Pringle ${ }^{1,2}$, H. Tost ${ }^{1}$, S. Message ${ }^{1}$, B. Steil ${ }^{1}$, D. Giannadaki ${ }^{1}$, A. Nenes ${ }^{3}$, C. Fountoukis ${ }^{4}$, P. Stier ${ }^{5}$, E. Vignati ${ }^{6}$, and \\ J. Lelieveld ${ }^{1,7}$ \\ ${ }^{1}$ Max Planck Institute for Chemistry, Mainz, Germany \\ ${ }^{2}$ School of Earth and Environment, University of Leeds, Leeds, UK \\ ${ }^{3}$ Schools of Earth \& Atmospheric Sciences and Chemical \& Biomolecular Engineering, Georgia Institute of Technology, \\ Atlanta, GA, USA \\ ${ }^{4}$ Institute of Chemical Engineering and High Temperature Chemical Processes, Foundation for Research and Technology - \\ Hellas, Patras, Greece \\ ${ }^{5}$ Atmospheric, Oceanic and Planetary Physics, Department of Physics, University of Oxford, Oxford, UK \\ ${ }^{6}$ Joint Research Centre, Institute for Environment and Sustainability, Climate Change Unit, Ispra, Italy \\ ${ }^{7}$ The Cyprus Institute, Energy, Environment and Water Research Centre, Nicosia, Cyprus
}

Received: 19 April 2010 - Published in Geosci. Model Dev. Discuss.: 20 May 2010

Revised: 30 August 2010 - Accepted: 2 September 2010 - Published: 10 September 2010

\begin{abstract}
We present a new aerosol microphysics and gas aerosol partitioning submodel (Global Modal-aerosol eXtension, GMXe) implemented within the ECHAM/MESSy Atmospheric Chemistry model (EMAC, version 1.8). The submodel is computationally efficient and is suitable for medium to long term simulations with global and regional models. The aerosol size distribution is treated using 7 log-normal modes and has the same microphysical core as the M7 submodel (Vignati et al., 2004).

The main developments in this work are: (i) the extension of the aerosol emission routines and the M7 microphysics, so that an increased (and variable) number of aerosol species can be treated (new species include sodium and chloride, and potentially magnesium, calcium, and potassium), (ii) the coupling of the aerosol microphysics to a choice of treatments of gas/aerosol partitioning to allow the treatment of semi-volatile aerosol, and, (iii) the implementation and evaluation of the developed submodel within the EMAC model of atmospheric chemistry.

Simulated concentrations of black carbon, particulate organic matter, dust, sea spray, sulfate and ammonium aerosol are shown to be in good agreement with observations (for all species at least $40 \%$ of modeled values are within a factor of 2 of the observations). The distribution of nitrate aerosol is compared to observations in both clean and polluted regions.
\end{abstract}

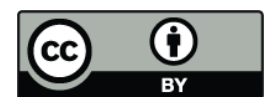

Correspondence to: K. J. Pringle (kirsty.pringle@mpic.de)
Concentrations in polluted continental regions are simulated quite well, but there is a general tendency to overestimate nitrate, particularly in coastal regions (geometric mean of modelled values/geometric mean of observed data $\approx 2$ ). In all regions considered more than $40 \%$ of nitrate concentrations are within a factor of two of the observations. Marine nitrate concentrations are well captured with $96 \%$ of modeled values within a factor of 2 of the observations.

\section{Introduction}

The importance of aerosol for climate and atmospheric processes has driven the development of global aerosol models with a wide range of complexities. The majority of these schemes treat 5 key aerosol species: black carbon, particulate organic carbon, sulfate, mineral dust and sea spray (for a review see Textor et al., 2006). Aerosol nitrate has received less attention despite it being a potentially important contributor to aerosol burden, particularly in highly industrialised regions (e.g. Malm et al., 2004; Zhang et al., 2007).

The first comprehensive global treatment of nitrate aerosol emerged over a decade ago (Adams et al., 1999), but the inclusion of nitrate has lagged behind that of other species in global aerosol models because it is semi-volatile, and predicting the partitioning of semi-volatile species is a complex problem; partitioning is driven by the thermodynamics of the system (the state that minimises the free energy of the

Published by Copernicus Publications on behalf of the European Geosciences Union. 
aerosol) and is a function of temperature, pressure and the aerosol chemical composition. A number of global aerosol models that can treat nitrate aerosol exist, and studies predict nitrate to be an important aerosol component under both present day (e.g., Adams et al., 1999, 2001; Metzger et al., 2002; Bauer and Koch, 2005; Myhre et al., 2006; Feng and Penner, 2007) and future conditions (e.g. Derwent et al., 2003; Bauer et al., 2007; Pye et al., 2009). The Fourth Assessment Report from the Intergovernmental Panel on Climate Change (Forster et al., 2007) estimated the radiative forcing of nitrate aerosols to be $-0.1 \pm 0.1 \mathrm{~W} \mathrm{~m}^{-2}$, but noted that the number of model studies which have calculated this parameter is "insufficient for accurate characterisation of the magnitude and uncertainty of the radiative forcing". There is therefore a continued need to develop aerosol models that can treat nitrate aerosol and can be used for climate and radiation studies.

Including the partitioning of nitrate between the gas and aerosol phases in models has an additional benefit in that it also allows the more detailed treatment of ammonium aerosol. Models that do not consider the partitioning typically assume that all sulfate is in the form of ammonium sulfate, thus the concentration of ammonium in the aerosol is simply implied from the concentration of sulfate. Treatment of the partition of the sulfate/nitrate/ammonium system allows the on-line calculation of ammonium concentrations, rather than assuming a fixed sulfate to ammonium ratio.

The purpose of the present paper is to introduce and document a new aerosol microphysics submodel called GMXe. The model is based on the M7 aerosol microphysics model (Wilson et al., 2000; Vignati et al., 2004; Stier et al., 2005) but it has a number of new features which make it a useful development for air quality and climate modelling studies. Firstly, GMXe can treat a wider range of species than traditional aerosol models; in addition to the standard species (black carbon, particulate organic matter, dust and sea spray), GMXe can also treat sodium, chloride, magnesium, potassium and calcium. The model also includes treatment of semi-volatile inorganic partitioning (e.g., nitrate and chloride). The model is introduced in Sects. 2 and 3 and compared against observations in Sect. 4.

\section{Host model description}

\subsection{The ECHAM/MESSy Atmospheric Chemistry (EMAC) model}

The Global Modal-aerosol eXtension (GMXe) submodel is implemented within the ECHAM/MESSy Atmospheric Chemistry model (EMAC, Version 1.8) - a combination of the ECHAM5 general circulation model (Roeckner et al., 2006, version 5.3.0.1) and the Modular Earth Submodel System (Jöckel et al., 2005, 2006). For a full description of the EMAC model and evaluation see Jöckel et al. $(2005,2006)$ or http://www.messy-interface.org. The MESSy system is modular and all submodels (including GMXe) follow strict coding standards to allow portability and modularity.

Various resolutions are possible in EMAC; in this study a spectral resolution of T42 degrees and 19 vertical levels was used. The model was "nudged" towards actual meteorology using ECWMF reanalysis data. In the simulations used in this work, the model was run for two years (2001 and 2002) with a spin-up period of six months.

A summary of the EMAC sub-modules used in this study is presented in Table 1. Gas-phase chemistry is simulated in EMAC with the MECCA submodel (Sander et al., 2005, Sect. 2.2). The wet deposition of gases and aerosols (initiated by both nucleation and impaction scavenging) is treated within the SCAV submodel (Tost et al., 2006b, 2007a), which describes scavenging due to convective and large-scale rain, snow and ice. Dry deposition is treated using the big leaf approach within the DRYDEP submodel (Ganzeveld and Lelieveld, 1995; Kerkweg et al., 2006a). Sedimentation of all aerosol types is treated within the SEDI submodel (Kerkweg et al., 2006a). Emission of gas and aerosols is treated by the ONLEM and OFFLEM routines (Kerkweg et al., 2006a). The other submodels used in this study are CONVECT (Tost et al., 2006b), LNOX (Tost et al., 2007b), TNUDGE (Kerkweg et al., 2006b), as well as CLOUD, CVTRANS, JVAL, RAD4ALL, and TROPOP (Jöckel et al., 2006).

\subsection{Gas phase chemistry}

The EMAC model calculates fields of gas phase species online through the MECCA submodel (via the Module Efficiently Calculating the Chemistry of the Atmosphere Sander et al., 2005). MECCA calculates the concentration of a range of gas phase species, including aerosol precursor species such as $\mathrm{SO}_{2}, \mathrm{NH}_{3}, \mathrm{HNO}_{3}, \mathrm{DMS}, \mathrm{H}_{2} \mathrm{SO}_{4}$ and DMSO. The concentrations of the major oxidant species $\left(\mathrm{OH}, \mathrm{H}_{2} \mathrm{O}_{2}\right.$, $\mathrm{NO}_{2}$, and $\mathrm{O}_{3}$ ) are also calculated online (see Sander et al., 2005; Jöckel et al., 2006).

In GMXe the loss of gas phase species to the aerosol through heterogeneous reactions (e.g., $\mathrm{N}_{2} \mathrm{O}_{5}$ to form $\mathrm{HNO}_{3}$ ) is treated using the HETCHEM submodel (e.g. Jöckel et al., 2006).

\subsection{Aqueous phase chemistry}

The aqueous phase oxidation of $\mathrm{SO}_{2}$ and the uptake of $\mathrm{HNO}_{3}$ and $\mathrm{NH}_{3}$ in cloud droplets is an important source of aerosol mass. In EMAC this is treated by the SCAV submodel (Tost et al., 2006b, 2007a), which can prognostically calculate the $\mathrm{pH}$ of clouds and precipitation, and calculates the aqueous phase redox reactions using a system of ordinary differential equations. Cloud droplet residuals formed from droplet evaporation (including any mass from in-cloud production) are reintegrated to the mode from which they were initially scavenged. If aqueous phase chemistry results in sufficient 
growth, the particles can be re-partitioned into other modes within GMXe (using the mode merging algorithm of Vignati et al., 2004).

\subsection{Wet scavenging of aerosol}

Wet removal of aerosol particles occurs via both nucleation and impaction scavenging. Whereas impaction scavenging is caused by the physical process of falling droplets and crystals and affects both hydrophobic and hydrophilic particles, nucleation scavenging (removal of activated aerosol particles) is only calculated for the hydrophilic modes. To determine the scavenged fraction of the particles per mode an empirical formula (see Tost et al., 2006a) is applied.

The material incorporated in cloud droplets via nucleation scavenging can either be (i) removed from the atmosphere based on the precipitation formation rate or (ii) released back into the aerosol phase after cloud evaporation. Furthermore, it can participate in chemical reactions in the aqueous phase (see above).

Due to the assumed internal mixing of the particles within the hydrophilic modes when hydrophillic aerosol are scavenged any coated hydrophobic cores, e.g. OC, BC are also scavenged. At present, the information of the nucleation scavenged particles is not used for determining the cloud droplet number concentration, which is in the current simulations a climatological value only.

\subsection{Bulk emissions}

Throughout this manuscript we make the distinction between aerosol species where the chemical composition is resolved and the individual ions that make up the compound are known (e.g. sodium or chloride) and species where the chemical composition is unresolved (here termed "bulk" species). Bulk species are generic aerosol species such as "dust" or "black carbon" which (in the atmosphere) are known to contain a range of different species, but which are treated as chemically inert within the model. With bulk species there is no resolution of the individual species that comprise the aerosol type.

In the model setup used in this study all primary (bulk) aerosol emissions are taken from the AEROCOM (an AEROsol module inter-COMparison in global models, http:// nansen.ipsl.jussieu.fr/AEROCOM/) recommendations compiled by Dentener et al. (2006). These emissions are all representative of the year 2000. The division of bulk emission streams to speciated emissions is treated within GMXe, and is described in Sect. 3.5.

\subsubsection{Dust and sea spray}

The mass flux of sea spray and mineral dust are treated using monthly mean emission files (Dentener et al., 2006), thus emissions are "offline" and not dependent on the simulated meteorology. Offline emission fields are used in this
Table 1. Summary of the EMAC submodels used in this study. HETCHEM is used to calculate stratospheric reaction rates (and the rate of conversion of $\mathrm{N}_{2} \mathrm{O}_{5}$ in the troposphere). TNUDGE nudges concentrations of long lived species (e.g. $\mathrm{CH}_{4}$ and $\mathrm{N}_{2} \mathrm{O}$ ) at the surface.

\begin{tabular}{lll}
\hline Submodel name & Purpose & Reference \\
\hline CLOUD & Clouds and precipitation & Jöckel et al. (2006) \\
CONVECT & Convection & Tost et al. (2010) \\
CVTRANS & Convective tracer transport & Tost et al. (2006b) \\
DRYDEP & $\begin{array}{l}\text { Dry deposition of gases } \\
\text { and aerosol }\end{array}$ & Kerkweg et al. (2006a) \\
& Heterogenous chemistry & Jöckel et al. (2006) \\
HETCHEM & Rates of photolysis & Jöckel et al. (2006) \\
JVAL & Lightning NO & Tost et al. (2007b) \\
LNOX & Chemical atmospheric & Sander et al. (2005) \\
MECCA & reactions & \\
& Offline emissions & Kerkweg et al. (2006b) \\
OFFLEM & Online emissions & Kerkweg et al. (2006b) \\
ONLEM & Radiation & Jöckel et al. (2006) \\
RAD4ALL & Wet deposition & Tost et al. (2006a) \\
SCAV & Tracer nudging & Kerkweg et al. (2006b) \\
TNUDGE & Jalculation of & Jöckel et al. (2006) \\
TROPOP & the tropopause & \\
& &
\end{tabular}

study given their extensive use and evaluation in a number of aerosol model frameworks (e.g. Textor et al., 2007). In taking this approach we acknowledge that the model will likely underestimate the inter-seasonal variability of dust and sea spray aerosol.

For sea spray we convert the mass flux to a number flux assuming a radius on emission of 0.156 and $0.85 \mu \mathrm{m}$ for the accumulation and coarse modes, respectively. This flux was calculated for AEROCOM using the sea spray flux parametrisation of Gong (2003). Mineral dust fields were calculated using the parametrisation of Ginoux et al. (2001) as used by Ginoux et al. (2003). We split the total dust mass flux between the coarse $(98.6 \%)$ and the accumulation $(1.4 \%)$ modes and emit with a number mean radius of 0.21 and $0.65 \mu \mathrm{m}$, respectively (Dentener et al., 2006). EMAC also has the option to calculate the emission of sea spray and mineral dust aerosol on-line (Kerkweg et al., 2006b), but in the simulations presented in this work this option was not used.

\subsubsection{Black carbon and particulate organic matter}

Black carbon (BC), particulate organic matter (POM) and secondary organic aerosol (SOA) emission data is also from Dentener et al. (2006). At emission, all BC is assumed to be hydrophobic, however, the POM aerosol is assumed to be partially hydrophilic $(65 \%)$ and partially hydrophobic $(35 \%)$ on emission (Stier et al., 2005). Once emitted, the species in BC and POM are simply "bulk" species; we do not consider the further oxidation of the organics within the aerosol. In 
Table 2. Example setup of the GMXe submodel, as used in this work (other combinations/setups are possible). Aerosol species are distributed between the 4 hydrophilic and 3 hydrophobic aerosol modes. $\mathrm{E}=$ Emitted into the mode, $\mathrm{P}=\mathrm{Permitted}$ in the mode. $\mathrm{BC}=$ black carbon, $\mathrm{POM}=$ particulate organic matter, $\mathrm{SS}=$ sea spray, $\mathrm{Du}=$ dust. $R_{\mathrm{p}}=$ radius $(\mathrm{nm})$.

\begin{tabular}{|c|c|c|c|c|c|c|c|c|c|c|c|c|}
\hline Mode & $R_{\mathrm{p}}$ & & $\mathrm{H}_{2} \mathrm{O}$ & $\mathrm{SO}_{4}^{2-}$ & $\mathrm{NO}_{3}^{-}$ & $\mathrm{Cl}^{-}$ & $\mathrm{NH}_{4}^{+}$ & $\mathrm{Na}^{+}$ & POM & $\mathrm{BC}$ & Du & SS \\
\hline \multicolumn{13}{|l|}{ Hydrophilic } \\
\hline Nucleation & $<5$ & NS & $\mathrm{P}$ & $\mathrm{P}$ & $\mathrm{P}$ & & $\mathrm{P}$ & & & & & \\
\hline Aitken & $5-50$ & KS & $\mathrm{P}$ & $\mathrm{P}$ & $\mathrm{P}$ & & $\mathrm{P}$ & & E & E & & \\
\hline Accumulation & $50-500$ & AS & $\mathrm{P}$ & $\mathrm{P}$ & $\mathrm{P}$ & E & $\mathrm{P}$ & E & $\mathrm{P}$ & $\mathrm{P}$ & $\mathrm{P}$ & $\mathrm{P}$ \\
\hline Coarse & $>500$ & CS & $\mathrm{P}$ & $\mathrm{P}$ & $\mathrm{P}$ & E & $\mathrm{P}$ & E & $\mathrm{P}$ & $\mathrm{P}$ & $\mathrm{P}$ & $\mathrm{P}$ \\
\hline \multicolumn{13}{|l|}{ Hydrophobic } \\
\hline Aitken & $5-50$ & $\mathrm{KI}$ & & & & & & & E & & & \\
\hline Accumulation & $50-500$ & AI & & & & & & & & & E & \\
\hline Coarse & $>500$ & CI & & & & & & & & & E & \\
\hline \multicolumn{13}{|l|}{ Bulk } \\
\hline Emission & & & & & & SS & & SS & POM & $\mathrm{BC}$ & Du & SS \\
\hline Stream & & & & & & & & & & & & \\
\hline
\end{tabular}

this work we do not treat the partitioning of secondary organic aerosol between the gas and particulate phase; SOA is emitted and transported as a bulk aerosol species (POM).

\section{GMXe model description}

\subsection{Model formulation}

The GMXe submodel comprises two parts:

- Microphysics: aerosol microphysics are treated using an extended version of the M7 modal aerosol scheme (Wilson et al., 2000; Vignati et al., 2004; Stier et al., 2005), which describes the aerosol distribution using 7 interacting lognormal aerosol modes; 4 hydrophilic modes and 3 hydrophobic modes. See Table 2 and Sect. 3.2.1.

- Gas/aerosol partitioning: a full thermodynamic treatment of gas/aerosol partitioning is prohibitively expensive for inclusion in global models, and even simplified thermodynamic models normally require iteration and thus can add significantly to the computational burden. In GMXe we have chosen to offer a choice of complexities: partitioning can be treated using either the ISORROPIA-II thermodynamic equilibrium model (Fountoukis and Nenes, 2007), or the EQSAM3 model (Metzger and Lelieveld, 2007).

A schematic overview of the GMXe model and how it is implemented in EMAC is shown in Fig. 1.

\subsection{The aerosol microphysics}

\subsubsection{The aerosol size distribution}

The aerosol size distribution is described by the supposition of 7 interacting lognormal modes (4 hydrophilic and 3 hydrophobic modes):

$n(\ln r)=\sum_{i=1}^{7} \frac{N_{i}}{\sqrt{2 \pi} \ln \sigma_{i}} \exp \left(-\frac{\left(\ln r-\ln \bar{r}_{i}\right)^{2}}{2 \ln ^{2} \sigma_{i}}\right)$

where each mode $(i)$ is defined in terms of the number concentration $\left(N_{i}\right)$, the number mean radius $\left(\bar{r}_{i}\right)$ and the geometric standard deviation $\left(\sigma_{i}\right)$.

The aerosol number and mass (the latter of each component) are calculated prognostically, but following Vignati et al. (2004) and Stier et al. (2005) the geometric standard deviation of the mode is fixed ( $\sigma=2.0$ for the coarse hydrophobic mode, $\sigma=2.2$ for coarse hydrophilic mode and 1.69 for the other modes). The choice of $\sigma=2.2$ for coarse hydrophilic mode is different to previous implementations of the M7 (Stier et al., 2005; Kerkweg et al., 2007), who use $\sigma=2.0$ (discussed in Sect. 4.2.1).

The 4 hydrophilic modes are arranged to cover the aerosol size spectrum (nucleation to coarse modes) from particles $<5 \mathrm{~nm}$ radius to those $>500 \mathrm{~nm}$ (Table 2). Each size range has a fixed size boundary but a variable mean radius. The 3 hydrophobic modes have the same size range, but no hydrophobic nucleation mode is required (Stier et al., 2005). The aerosol composition within each mode is uniform with size, but the composition can vary between modes.

One main difference between the formulation of the M7 and GMXe microphysics is that the code has been generalised so that the model is not limited to a fixed number 


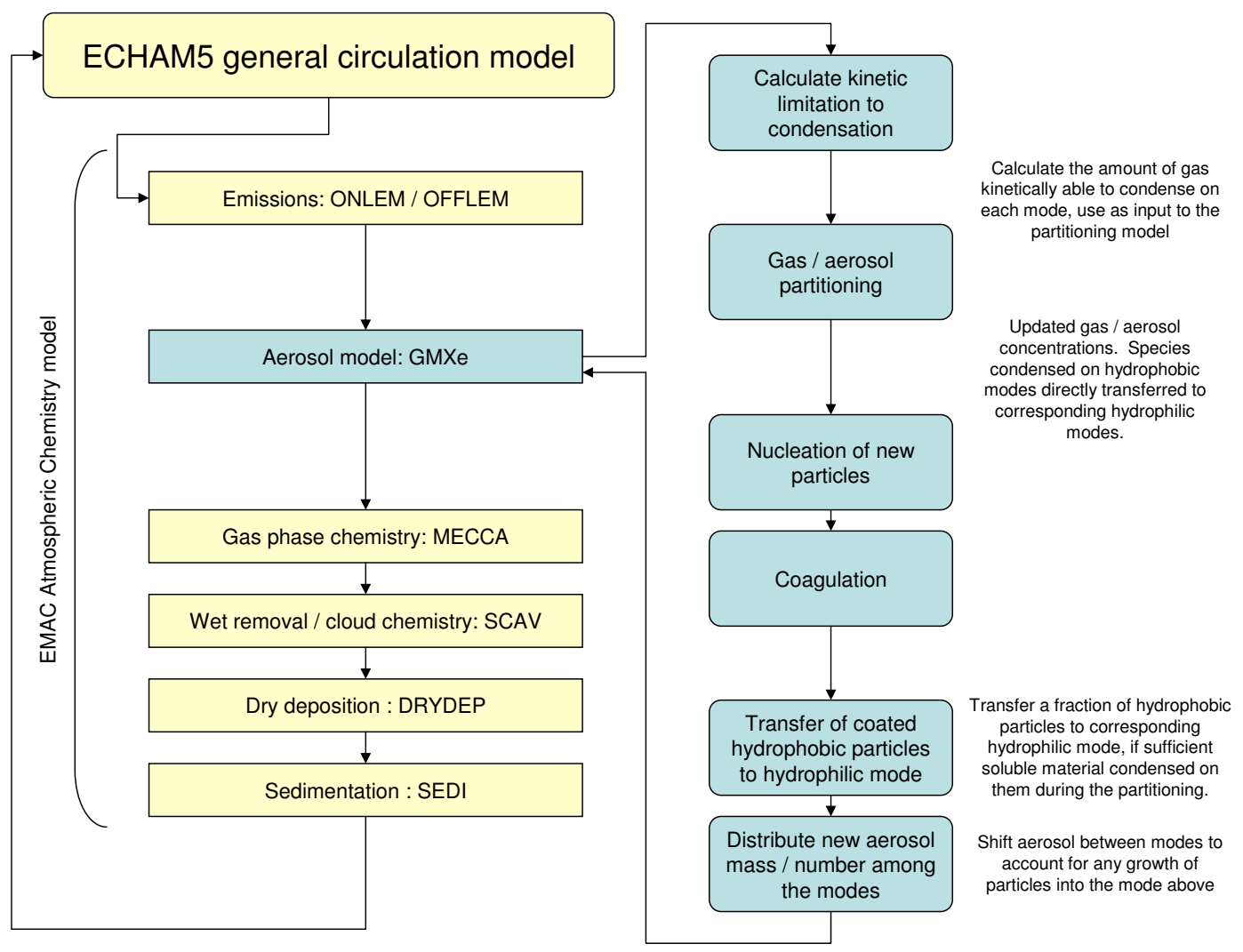

Fig. 1. Graphic summarising the calling sequence of the processes in the GMXe model, implemented within the ECHAM/MESSy Atmospheric Chemistry model.

or type of species - GMXe can treat an increased number of aerosol species compared to the M7 (which simulates 5 aerosol species) and the number of species simulated can be varied to suit the setup required (so ensemble runs of differing complexities can be done).

Table 2 shows the setup of the aerosol model used in this introductory paper. In this work we consider the major ions present within sea spray (sodium and chloride) but neglect more minor marine species (e.g. magnesium) and we also neglect the cations present within mineral dust aerosol or BC (e.g. calcium and potassium). Treatment of these species is also possible in GMXe (Sect. 3.5) but these species will be the focus of future work.

\subsubsection{Nucleation of new particles}

Nucleation of new particles is calculated as a function of the temperature, relative humidity and the concentration of sulfuric acid $\left(\mathrm{H}_{2} \mathrm{SO}_{4}\right)$. Two binary nucleation schemes are available in GMXe; the scheme of Vehkamaki et al. (2002) and that of Kulmala et al. (1998). In this work we use the Vehkamaki et al. (2002) scheme, this parametrisation is valid over the range $0.01 \%<\mathrm{RH}<100 \%$ and $190 \mathrm{~K}<$ $T<305.15 \mathrm{~K}$.

\subsubsection{Coagulation}

Coagulation is treated following Vignati et al. (2004); coagulation coefficients are calculated for Brownian motion using Fuchs (1964). In GMXe the coagulation matrix has been generalised to handle a variable number of species per mode. Coagulation can potentially move aerosol from smaller to larger modes and from hydrophobic to hydrophilic modes. As in M7, GMXe assumes that the coagulation of two particles from the same mode will form a new particle in that mode (e.g. $\mathrm{KS}+\mathrm{KS}=\mathrm{KS}$ ), and two particles from different modes will form a new particle in the larger mode (e.g. $\mathrm{KS}+\mathrm{AS}=\mathrm{AS}$ ). Coagulation between hydrophilic and hydrophobic modes produces a new particle in the larger of the hydrophilic modes (e.g. AI $+\mathrm{KS}=\mathrm{AS}$ ) (where $\mathrm{KS}=$ Aitken soluble (hydrophilic) and $\mathrm{AS}=$ accumulation soluble (hydrophilic) and $\mathrm{AI}=$ Aitken insoluble (hydrophobic)).

\subsection{Gas/aerosol partitioning}

Treatment of the gas/aerosol partitioning of the semivolatile inorganic species is done in GMXe through either ISORROPIA-II or EQSAM3. Both schemes are set within the same framework so inter-comparison studies can be carried out. The schemes are described briefly below. 


\subsubsection{The ISORROPIA-II model}

ISORROPIA-II is an inorganic equilibrium model that is able to calculate the gas/aerosol/solid equilibrium partitioning of the main atmospherically relevant inorganic semi-volatile species (Fountoukis and Nenes, 2007). It is an extension of the ISORROPIA model (Nenes et al., 1998a,b) and is able to treat the interaction of $\mathrm{K}, \mathrm{Ca}, \mathrm{Mg}, \mathrm{NH}_{4}, \mathrm{Na}, \mathrm{SO}_{4}, \mathrm{NO}_{3}$, $\mathrm{Cl}, \mathrm{H}_{2} \mathrm{O}$ aerosols. Gas-phase species considered are $\mathrm{NH}_{3}$, $\mathrm{HCl}, \mathrm{HNO}_{3}, \mathrm{H}_{2} \mathrm{O}$; aerosol phase species include all major ionic and solid salts formed by $\mathrm{K}, \mathrm{Ca}, \mathrm{Mg}, \mathrm{NH}_{4}, \mathrm{Na}, \mathrm{SO}_{4}$, $\mathrm{NO}_{3}, \mathrm{Cl}$. In cases where aqueous solutions are present, $\mathrm{H}^{+}$, $\mathrm{OH}^{-}$and undissociated forms of $\mathrm{HNO}_{3}, \mathrm{NH}_{3}, \mathrm{HCl}$ are also considered.

ISORROPIA-II solves for the equilibrium state by considering the chemical potential of the species (Nenes et al., 1998a,b). By considering specific compositional "regimes", it minimises the number of equations and iterations required. Because of this, it is considered one of the most computationally efficient thermodynamic equilibrium models available. In ISORROPIA-II, the aerosol can be in either a thermodynamically stable state (where salts precipitate once the aqueous phase becomes saturated) or in a metastable state (where the aerosol is composed only of a supersaturated aqueous phase). The model can solve for either: (i) "forward" problems where the total (i.e., gas + aerosol) concentrations are known and the gas/aerosol concentrations are predicted, or (ii) "reverse" problems where the aerosol concentration is known and the gas concentrations are predicted. In this work we use ISORROPIA-II in the "forward" mode.

ISORROPIA-II also offers the options to (i) calculate activity coefficients on-line or (ii) use pre-calculated look up tables (the latter of which is used in this study). Since its release, ISORROPIA-II has been used in a number of global (Pye et al., 2009) and urban-scale (Fountoukis et al., 2009; Karydis et al., 2010) model studies.

\subsubsection{The EQSAM3 model}

The EQSAM3 model is a simplified, non-iterative, treatment of gas/aerosol partitioning that uses analytical expressions based on species solubility (Metzger and Lelieveld, 2007). Compared to other treatments of partitioning, EQSAM3 is more flexible as it is easily expandable to treat additional inorganic ions and speciated organics. The model can be run in a range of complexities, in this work we consider the same cations as treated by ISORROPIA-II and no speciated organics. Sensitivity to increased complexity will be considered in future work.

EQSAM3 calculates the amount of species partitioning to the aerosol phase through the use of a "neutralisation order", this order is used to rank the ions in terms of their ability to form a neutral salt. There are two options available to calculate the neutralisation order in EQSAM3:
1. Order calculated online by EQSAM3 (see Metzger and Lelieveld, 2007), based on the deliquescence relative humidity of the species present.

2. Order prescribed according to the Hofmeister series (Hofmeister, 1888; Metzger and Lelieveld, 2007):

(a) Anions: $\mathrm{SO}_{4}{ }^{2-}, \mathrm{HSO}_{4}{ }^{-}, \mathrm{NO}_{3}{ }^{-}, \mathrm{Cl}^{-}, \mathrm{OH}^{-}$.

(b) Cations: $\mathrm{Na}^{+}, \mathrm{NH}_{4}{ }^{+}, \mathrm{H}^{+}$.

In this work we use the order prescribed by the Hofmeister series.

The neutralisation order determines which ions are paired to form a salt first; ions are paired by taking the first cation $\left(\mathrm{Na}^{+}\right)$and looping over all anions and then then moving to the next cation $\left(\mathrm{NH}_{4}{ }^{+}\right)$, and so on. In this way neutral compounds are formed using ions at the top of the order first. Pairing is only permitted if there are sufficient cations and anions in the solution. Once no more neutral solute can form, any un-paired cations or anions are assumed to stay in the aqueous phase, and un-neutralised gases $\left(\mathrm{NH}_{3}, \mathrm{HNO}_{3}\right.$ and $\mathrm{HCl}$ ) are assumed to partition to the gas phase. For semivolatile species $\left(\mathrm{NH}_{4} \mathrm{NO}_{3}\right.$ and $\mathrm{NH}_{4} \mathrm{Cl}$ ), a further loss (from the aerosol phase) is calculated using a relation based on activity coefficients (Metzger and Lelieveld, 2007).

EQSAM3 is developed and maintained as part of the ECHAM/MESSy group, and will be further developed to include additional aerosol compounds e.g. sugars.

\subsubsection{The aerosol water content}

Water is an important parameter as it often constitutes the bulk of the particle volume, and changes in the aerosol water loading can alter the aerosol wet radius and thus affect the interaction of the particle with condensable gases and radiation. The parametrisation of ambient water uptake varies greatly between aerosol models; ranging from simplified empirical parametrisation (e.g. that of Gerber, 1991) to treatments that take the activity of multi-component aerosols into account. Textor et al. (2006) found that there was a broad range in aerosol water contents predicted by the AEROCOM models, partly due to the range of parametrisations used. In the setup used in this work, ISORROPIA-II (or EQSAM) is used to calculate water uptake on inorganic species, water uptake onto organic species is not permitted. As the calculation of aerosol water is valid for subsaturated conditions only, the relative humidity used within GMXe is set to be $<98 \%$.

\subsubsection{Non-equilibrium considerations}

ISORROPIA-II and EQSAM3 calculate the partitioning of species assuming that the aerosols are in equilibrium with the gas phase. While this is a good approximation for small particles which reach equilibrium quickly (within a model time step), larger particles may not be in equilibrium with their surroundings, especially if temperatures are low (e.g. 
Meng and Seinfeld, 1996; Wexler and Seinfeld, 1992; Capaldo et al., 2000). Non-equilibrium can occur in large particles as they are subject to mass transfer limitations. Assuming the whole aerosol size distribution to be in equilibrium will bias the calculation of the amount of aerosol in fine and coarse modes (e.g. Capaldo et al., 2000; Feng and Penner, 2007; Karydis et al., 2010).

Some models account for non-equilibrium conditions by only considering the gas/aerosol partitioning on the fine modes and excluding the formation of sulfate-nitrateammonium on coarse mode aerosol (e.g. Pye et al., 2009) or by neglecting the coarse mode aerosol either (i) entirely (e.g. Lauer et al., 2005; Lauer and Hendricks, 2006), or, (ii) partially (e.g. Bauer et al., 2007, who neglect nitrate formation on sea salt). But the above approach is at odds with field observations which have shown that a significant amount of nitrate aerosol can be present in the coarse mode (e.g. Pakkanen, 1996; Zhuang et al., 1999). For example in a field study in two polluted coastal regions Yeatman et al. (2001) found that between 40 to $81 \%$ of the total nitrate present in the aerosol phase was found in the coarse mode.

A more sophisticated way of treating the different modes is that of Capaldo et al. (2000) who calculate composition using a hybrid dynamic approach. This hybrid approach has been used in a global aerosol model (Feng and Penner, 2007), but the additional calculation required adds to the computational overhead of the model.

To account for kinetic limitations in GMXe the process of gas/aerosol partitioning is calculated in two stages. In the first stage the amount of gas phase species kinetically able to condense onto the aerosol (within a timestep) is calculated (assuming diffusion limited condensation, following Fuchs, 1959; Vignati et al., 2004). This calculation of the kinetic limitation to condensation is the same as that used to treat condensation of $\mathrm{H}_{2} \mathrm{SO}_{4}$ in the $\mathrm{M} 7$ (Vignati et al., 2004), but it has been extended to also treat $\mathrm{NH}_{3}, \mathrm{HCl}$ and $\mathrm{HNO}_{3}$. The calculation uses an accommodation coefficient for each species, this was taken as $0.1,0.064$ and 0.09 for $\mathrm{HNO}_{3}, \mathrm{HCl}$, $\mathrm{NH}_{3}$ respectively (Vandoren et al., 1990; Hanisch and Crowley, 2003). These values are similar to the values used by Feng and Penner (2007), being 0.193 for $\mathrm{HNO}_{3}$ and 0.09 for $\mathrm{NH}_{3}$.

The second stage of the partitioning is the thermodynamic consideration. Once the total amount of gas that could kinetically condense to each mode is calculated, the chosen partitioning model (ISORROPIA-II or EQSAM3) is used to re-distribute the mass between the gas and the aerosol phase. Hence, for a low volatility species, e.g. $\mathrm{H}_{2} \mathrm{SO}_{4}$, the total amount that condenses is simply the amount that is kinetically able to condense (Vignati et al., 2004; Stier et al., 2005). For a semi-volatile species, only a fraction of the gas that is kinetically able to condense will partition to the aerosol phase (as dictated by the thermodynamics).

\subsection{Transfer of aerosol between modes}

The aerosol microphysics routines described above can result in aerosol changing from hydrophobic to hydrophilic (e.g. through condensation or coagulation with hydrophilic material). To account for this in GMXe, the transfer of material from the hydrophobic to the hydrophilic modes is calculated in two places:

1. After coagulation: when a hydrophobic and hydrophilic particle coagulate the resulting mass is assumed to reside in the hydrophilic mode.

2. After gas/aerosol partitioning: any soluble material that partitions onto the hydrophobic modes is transferred directly to the hydrophilic modes, along with a fraction of the hydrophobic material. The amount of hydrophobic material transferred (mass and number) is calculated from the fraction of the particles that is able to receive five monolayer coverage of hydrophilic material.

The use of a monolayer approach was introduced by Vignati et al. (2004) and used by Stier et al. (2005) to express the ageing of hydrophobic particles into hydrophilic modes. When sufficient hydrophilic material is added to the hydrophobic modes such that "n" monolayers of hydrophilic material could be created, the material is transferred between modes. Vignati et al. (2004) varied " $n$ " in a box model and found that $\mathrm{n}$ equal to 1 gave the best agreement to a detailed sectional model. In GMXe, $\mathrm{n}$ equal to 5 is chosen, as more material is available for condensation compared to Vignati et al. (2004, who treat condensation of $\mathrm{H}_{2} \mathrm{SO}_{4}$ only). In GMXe, the larger monolayer threshold gave better comparison of $\mathrm{BC}$ and dust aerosol to observations. The value of $n$ nethertheless is an adjustable parameter in the model (and in other models that take the monolayer approach, for example the GLOMAP-mode model which uses a monolayer threshold of 10; Mann et al., 2010). This larger threshold is in line with the finding of Granat et al. (2010) who examined aerosol concentrations in precipitation in the Maldives and found that soot aerosol could remain hydrophobic for many days after emission. Modal aerosol models (including GMXe) would benefit from additional laboratory and field studies into particle ageing which could better constrain how much hydrophilic material is required to make a hydrophobic particle hydrophilic.

Atmospheric processing can also result in growth of the aerosol so that particles can exceed the bounds of the size categories (Table 2, first column). In GMXe the final step (after the microphysics and gas/aerosol partitioning have been calculated) is to calculate the re-distribution of aerosol between the size categories using a mode merging algorithm (Vignati et al., 2004). This ensures that the count median radii of each mode are within the fixed boundaries. The redistribution is only calculated for the hydrophilic modes as it is assumed that the microphysical processes will move material from the hydrophobic to hydrophilic modes (where it 
will then be re-distributed later). Except for the choice of a larger monolayer threshold, the transfer of the aerosol between modes in GMXe is the same as that of ECHAM HAM (Stier et al., 2005).

\subsection{Bulk or speciated emissions}

The presence of ions within an aerosol has been shown to affect the balance of gas/aerosol partitioning (e.g. Jacobson, 1999; Metzger et al., 2006; Fountoukis et al., 2009), thus to improve the treatment of semi-volatile species it is important to consider the chemical makeup of the aerosol and not simply the bulk species. One study that has done this is that of Rodriguez and Dabdub (2004) who sub-divide the emission streams of the bulk dust and sea spray into the ionic constituents (e.g. $\mathrm{Na}^{+}, \mathrm{Ca}^{2+}$ ) in order to simulate the ionic composition for use in calculating the gas/aerosol partitioning.

GMXe takes a similar approach to that of Rodriguez and Dabdub (2004); it offers the flexibility to subdivide each of the four "bulk" emission streams (BC, POM, SS and Du) into speciated emissions (e.g. $\mathrm{Na}^{+}, \mathrm{Ca}^{2+}, \mathrm{K}^{+}$). Each "bulk" emission stream (BC, POM, SS or Du) can be either (i) left as bulk or (ii) be semi (or fully) speciated.

For example, the sea spray aerosol can be treated in two different ways:

1. Bulk: the sea spray is emitted into a "bulk" sea spray distribution, which has the same molecular weight and density as $\mathrm{NaCl}$, but the individual ions that comprise the aerosol are not simulated (and therefore not permitted to interact with other ions in the calculation of partitioning).

2. Speciated: the mass flux of emitted sea spray aerosol is split into its constituent ions $\left(\mathrm{Cl}^{-}, \mathrm{Na}^{+}, \mathrm{SO}_{4}{ }^{2-}\right.$ and also potentially $\mathrm{Mg}^{2+}$, etc.) based e.g. on the ionic composition of sea water. The individual ions are then transported as tracers (and passed into the partitioning routines for thermodynamic calculations).

Similarly the dust, BC and POM emission streams can also be subdivided, e.g. calcium could be emitted as a fixed fraction of the dust mass flux. In addition to setting up the emission streams, the user can also control which of the simulated species is "permitted" to exist in each mode. It is possible to simulate any of the available species in any of the modes (although of course not all combinations are realistic). An example model setup is shown in Table 2. The flexible nature of the design allows one to choose the species simulated (and their sources) to suit the problem at hand. The control of the division of bulk emission streams into speciated emissions and the switches controlling which species is "permitted" in each mode is controlled via a simple include file. The electronic supplement gives a tutorial to help with the initial model setup.

\section{Results and evaluation}

The simulations shown in this section were performed with the model setup shown in Table 2. Unless otherwise specified, the calculation of gas/aerosol partitioning was done using the ISORROPIA-II model. Simulated species were BC, POM, bulk sea spray, dust, $\mathrm{SO}_{4}^{2-}, \mathrm{NO}_{3}^{-}, \mathrm{NH}_{4}{ }^{+}, \mathrm{Na}^{+}, \mathrm{Cl}^{-}$ and $\mathrm{H}_{2} \mathrm{O}$. The sea spray flux was divided as follows; $85 \%$ by mass was split to form a flux of $\mathrm{Na}^{+}$and $\mathrm{Cl}^{-}$ions, $5 \%$ was assumed to be sodium sulfate and the remaining fraction was assumed to be "bulk" sea salt. This follows the approximate composition of sea water (Castro and Huber, 2003), where the bulk flux comprises species such as marine organics, $\mathrm{Mg}$ and $\mathrm{K}$, which are not treated in this setup. The other emissions streams were not speciated (bulk only).

\subsection{Aerosol number concentration}

The aerosol microphysics control the particle number and size distribution. The microphysics used in GMXe are the same as those of the M7 model (as used in a global study by Stier et al., 2005), thus here we only briefly present a summary of the key properties.

As a first evaluation step we present simulated fields of number concentration in the same format as those presented by Stier et al. (2005) using the ECHAM-HAM model. Comparison of GMXe fields with ECHAM-HAM fields is useful as ECHAM-HAM is a well established and widely used aerosol model (e.g. Stier et al., 2006; Lohmann et al., 2007) and the inter-model comparison gives a global overview of the number concentration (per mode) that is not easily achieved from field observations. The zonal mean annual average aerosol number concentrations simulated by GMXe are shown in Figs. 2 and 3. For evaluation, our Figs. 2 and 3 is comparable to the number concentrations shown by Stier et al. (2005) in their Fig. 4.

Differences between GMXe and ECHAM-HAM aerosol fields are to be expected as Stier et al. (2005) simulate a different year, use a higher resolution, use off-line oxidant fields and have a different treatment of wet deposition. However, despite these differences, GMXe simulates fields of zonal mean number that are in line with those of ECHAM-HAM. Both models capture the high number concentrations in nucleation and Aitken hydrophilic modes in the upper troposphere where new particle formation occurs. The distribution of the hydrophobic particles largely reflects the distribution of the $\mathrm{POM}, \mathrm{BC}$ and dust emissions. The main difference between GMXe and ECHAMHAM is that GMXe shows larger number concentrations in the coarse hydrophilic mode at high altitudes, implying stronger vertical transport (e.g. above $500 \mathrm{hPa}$ GMXe predicts concentrations of $0.2-0.5 \mathrm{~cm}^{-3}$, but ECHAM-HAM concentrations are $<0.2 \mathrm{~cm}^{-3}$ ). The other large difference is in the accumulation hydrophilic mode where the strong minima $\left(<0.05 \mathrm{~cm}^{-3}\right)$ simulated by ECHAM-HAM at the poles 

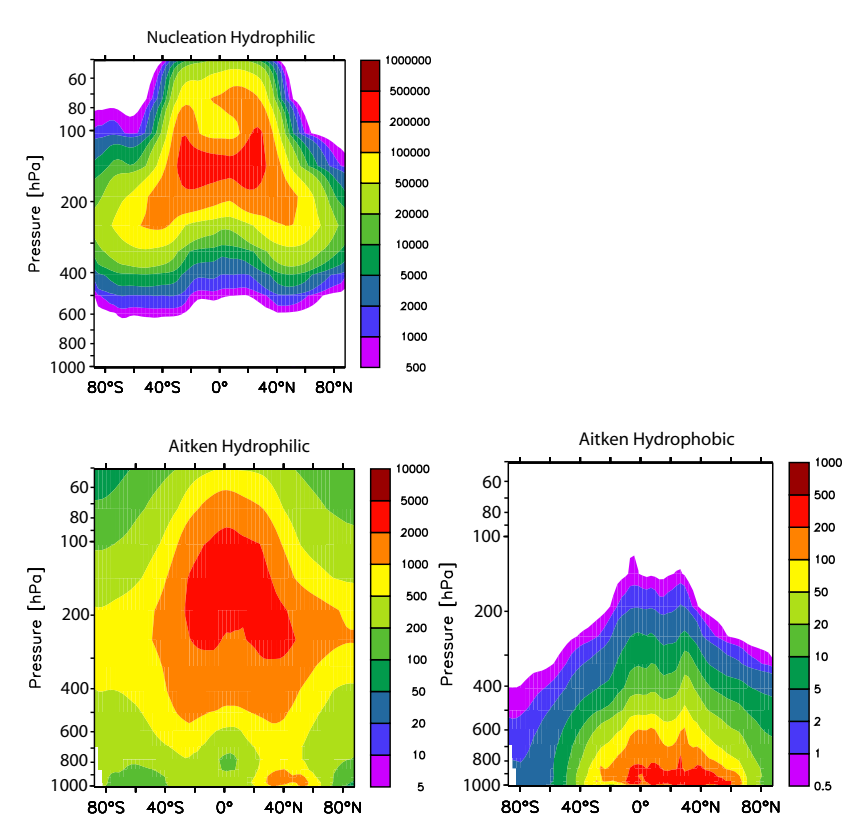

Fig. 2. Zonal and annual mean aerosol number concentration (converted to STP conditions at $1013.25 \mathrm{hPa}$ and $273.15 \mathrm{~K}, \mathrm{~cm}^{-3}$ ) for the year 2001 for the (top left) nucleation hydrophilic, (bottom left) Aitken hydrophilic and (bottom right) Aitken hydrophobic modes as simulated by GMXe.

at $500 \mathrm{hPa}$ is not simulated in GMXe (number concentrations of $20-50 \mathrm{~cm}^{-3}$ are simulated instead), however observations in this region are limited so it is difficult to determine the bias of either model.

Andreae (2009) collected observed values of condensation nuclei $(\mathrm{CN})$ concentrations taken from a range of field campaigns and field sites around the world. The standard definition of the $\mathrm{CN}$ concentration is the number of particles with dry diameter $>3 \mathrm{~nm}$, but Andreae (2009) also included some data which used a larger reference diameter. In Fig. 4 we show the annual mean CN concentration simulated by the model, with values summarised by Andreae (2009) over-plotted. Only a qualitative comparison can be made as we compare annual mean model data with observation data taken over a range of time periods (some short term from field campaigns lasting only a few weeks and some multiannual mean), but to maximise the amount of comparison data we do not exclude short-term data.

The comparison of modelled and observed values shows good agreement; low values $\left(\sim 200-500 \mathrm{~cm}^{-3}\right)$ are seen in the remote marine regions, and larger values $(500$ $2000 \mathrm{~cm}^{-3}$ ) in marine environments influenced by continental outflow. Values larger than $5000 \mathrm{~cm}^{-3}$ are simulated in polluted regions of Europe and Asia, also in line with the observations.

The Global Atmospheric Watch (http://wdca.jrc.it/data/ aerosol_program.html) program has collated a range of aerosol data from a number of observation stations. In Fig. 5 we compare simulated aerosol number concentrations
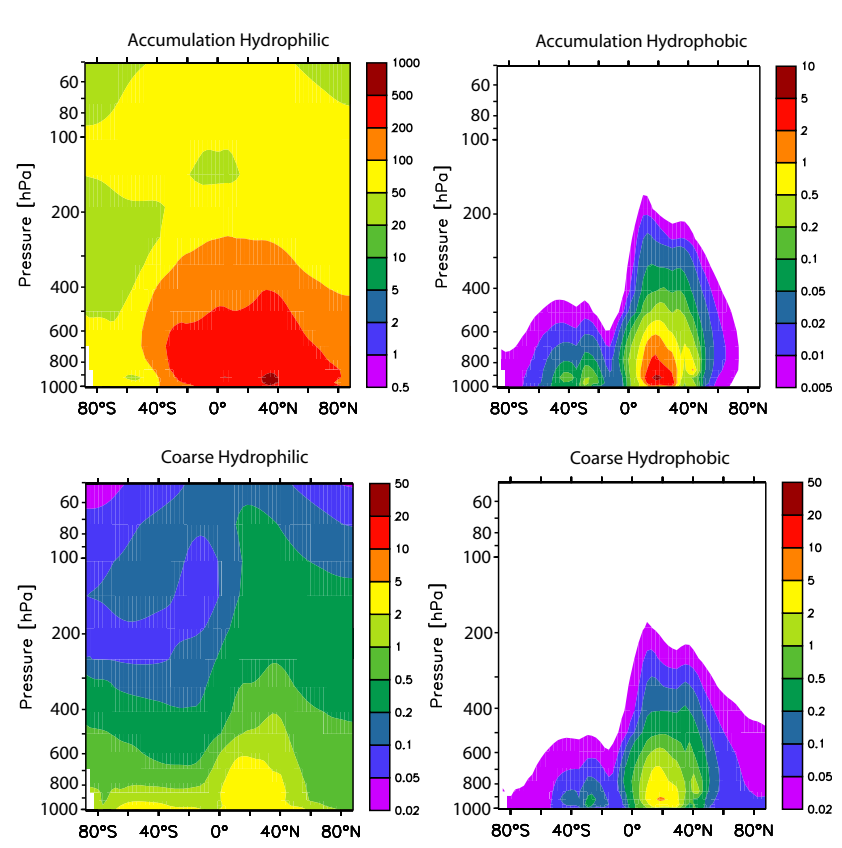

Fig. 3. As Fig. 2 but for the (top left) accumulation hydrophilic, (top right) accumulation hydrophobic, (bottom left) coarse hydrophilic and (bottom right) coarse hydrophobic modes.

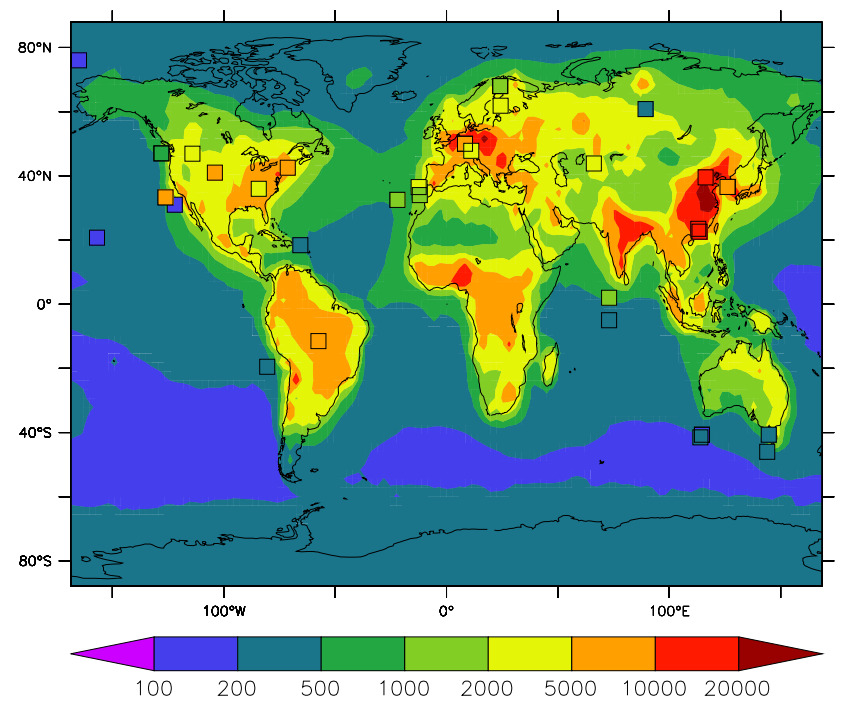

Fig. 4. Annual mean surface aerosol number concentration $\left(\mathrm{cm}^{-3}\right)$ compared to observed values (from a range of time periods) collected by Andreae (2009). Simulated values show total particle number in the Aitken, accumulation and coarse modes. Observations have a range of cutoff diameters.

against the four boundary layer GAW sites which have data for both 2001 and 2002. GMXe simulates the aerosol number concentration in the Southern Great Plains (North America) site with good agreement, although the model tends to underestimate compared to observations (simulated annual average of $4316 \mathrm{~cm}^{-3}$ cf. $5614 \mathrm{~cm}^{-3}$ ). Both model 

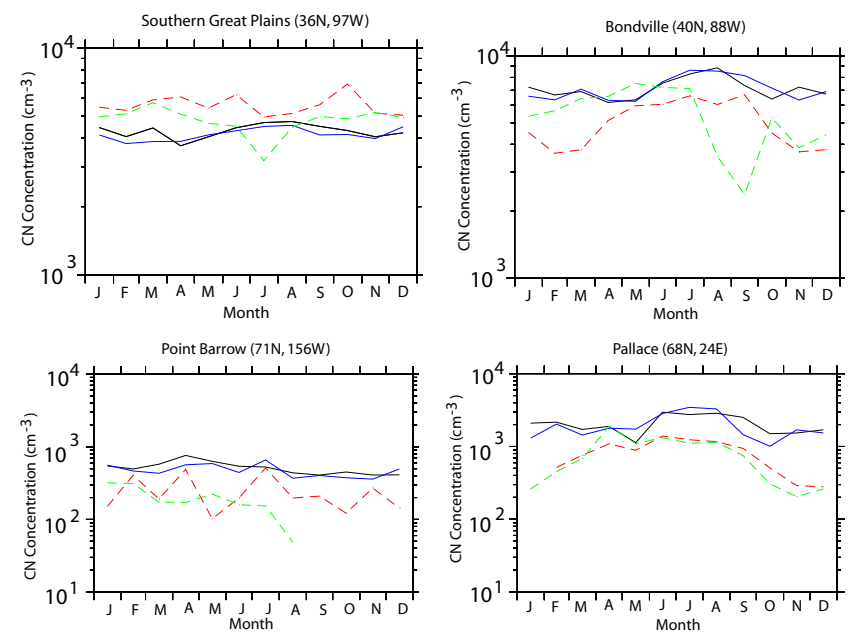

Fig. 5. Seasonal cycle of aerosol number concentration $\left(\mathrm{cm}^{-3}\right)$ in four locations as measured by the Global Atmopsheric Watch network. Lines show modelled values for 2001 (black) and 2002 (blue) and observed values for 2001 (red dash) and 2002 (green dash).

and observations show no distinct seasonal cycle. Aerosol number, however, is overestimated (simulated annual mean of $7149 \mathrm{~cm}^{-3} \mathrm{cf} .5045 \mathrm{~cm}^{-3}$ ) in the nearby Bondville site. In the remote continental sites of Barrow (Alaska) and Pallas (Finland) the model systematically overestimates number (Barrow simulated annual mean of $515 \mathrm{~cm}^{-3} \mathrm{cf} .248 \mathrm{~cm}^{-3}$; Pallas simulated annual mean of $1818 \mathrm{~cm}^{-3} \mathrm{cf} .825 \mathrm{~cm}^{-3}$ ). Additionally, GMXe fails to capture the observed seasonal cycle in Pallas with observations showing a decrease in aerosol number in winter months but the model showing much less seasonal variation.

\subsection{Global distribution of aerosol mass}

Throughout the following sections the following metrics will be used to evaluate model performance:

1. GMR is the geometric mean of the modelled values/the geometric mean of the observed concentrations.

2. $A M R$ is the arithmetic mean of the modelled values/the arithmetic mean of the observed concentrations.

3. PF2 is the percentage of model points where the respective species concentrations deviate from the observations by less than a factor of two.

The use of a range of different metrics is advantageous as each metric is susceptible to different biases, for example PF2 is not biased by data points that are very far from the median and is a useful metric for giving an overview of performance, but it gives no indication if the deviation between model and observations is systematic (e.g. constant underestimation) or random, which can be seen from GMR and AMR. By combining the three metrics we gain an overview of model performance.
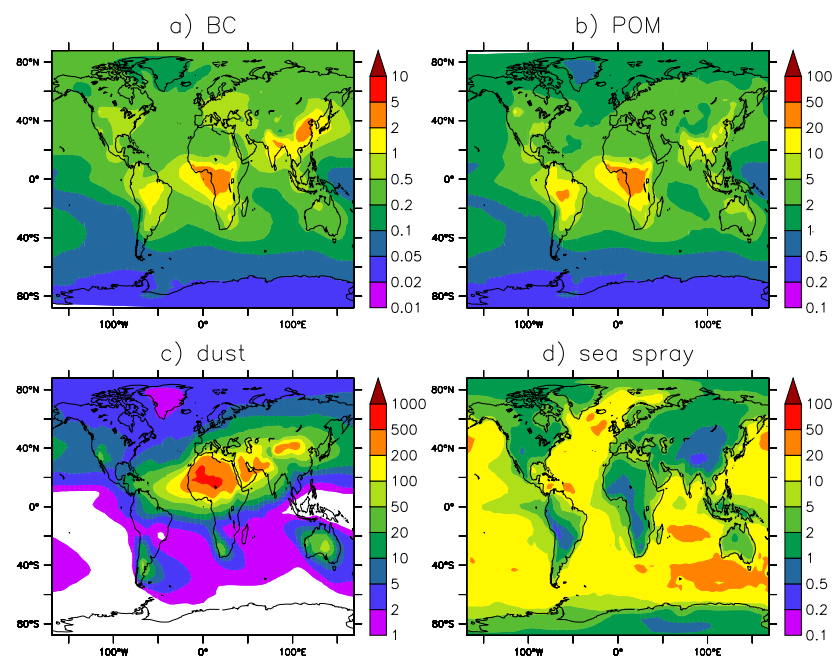

Fig. 6. Annual mean column tropospheric burden of the total concentration of (a) BC, (b) POM, (c) dust, (d) sea salt. The concentration of sea salt is calculated as the sum of sodium and chloride and bulk sea salt concentrations. All units are in $\mathrm{mg} \mathrm{m}^{-2}$.

\subsubsection{Bulk species: BC, POM, dust and sea spray}

Figures 6 shows the 2-year annual mean vertically integrated tropospheric burden of the bulk species simulated (summed over all modes, all model levels with pressure $>150 \mathrm{hPa}$ are assumed to be tropospheric). The burden of the species largely reflects the distribution of emissions; BC and POM concentrations are high over the biomass burning region of central Africa and South America, with additional maxima over India and China. Dust concentrations show the strong emission regions of Africa and Asia, and some intercontinental transport including the outflow of Saharan dust over the Atlantic. In general the distribution of the species is similar to that simulated using ECHAM-HAM (as shown in Stier et al., 2005, their Fig. 2).

The simulated annual mean concentration of BC, POM, dust and sea spray is compared to measurements in Fig. 8 and summarised in Table 3. Dust aerosol is well simulated (compared to the University of Miami data set) both close to and far from sources, although there is generally a low bias $(\mathrm{AMR}=0.83, \mathrm{GMR}=0.58, \mathrm{PF}=42)$. Dust emissions have a large inter-annual variability thus it is advantageous to compare to datasets that span a number of years (as done here), but in these simulations we use offline dust emissions representative of the year 2000 thus we will underestimate the inter-annual variability in dust concentrations.

$\mathrm{BC}$ and POM are compared to measurements from the IMPROVE network (http://vista.cira.colostate.edu/improve/) and thus are for North America only, but show good comparison with observations $(\mathrm{AMR}=0.96$ and 1.46 , respectively, $\mathrm{PF} 2 \geq 90 \%$ ). As the IMPROVE sites are all rural locations this comparison does not cover the full range of observed concentrations in different regions of North America. In the 
Table 3. Summary of the comparison of model data (2001 and 2002) to observations of bulk species (as shown in Fig. 8 with simulations performed using ISORROPIA and EQSAM3 to treat gas/aerosol partitioning). AMR is the arithmetic mean of the modelled values/the arithmetic mean of the observed values; GMR is the geometric mean of the modelled values/the geometric mean of the observed values; PF2 = Percentage of modelled points within a factor of two of the observations.

\begin{tabular}{llllllr}
\hline & \multicolumn{3}{c}{ GMXe-ISORROPIA } & \multicolumn{3}{c}{ GMXe-EQSAM3 } \\
Species & AMR & GMR & \multicolumn{1}{c}{ PF2 } & AMR & GMR & \multicolumn{1}{c}{ PF2 } \\
\hline Dust & 0.83 & 0.58 & 42.85 & 0.81 & 0.60 & 42.86 \\
Sea Salt & 1.15 & 1.95 & 61.76 & 1.08 & 1.82 & 61.76 \\
BC & 0.96 & 0.98 & 100.00 & 0.99 & 0.98 & 100.00 \\
POM & 1.46 & 1.31 & 91.67 & 1.48 & 1.33 & 83.30 \\
\hline
\end{tabular}

future the good agreement between model and observations will be investigated further with comparison of a higher resolution model to data taken from a wider range of environments (including polluted regions and regions of biomass burning).

To compare with bulk sea spray observations, we sum the mass of $\mathrm{Na}^{+}, \mathrm{Cl}^{-}$and bulk sea spray to give a total sea spray concentration. Concentrations are well captured in marine regions although there is a slight high bias. In coastal regions sea salt concentrations are overestimated by up to an order of magnitude (overall, GMR $=1.94, \mathrm{PF} 2=62 \%$ ). A similar bias was also noted in the ECHAM-HAM model (using online emissions), and Stier et al. (2005) suggest that it is due to artificial transport by averaging over large grid boxes, thus underestimating the sharp concentration gradients that occur in coastal regions.

In the simulations presented here, the hydrophilic coarse mode is assumed to have a geometric standard deviation $(\sigma)$ of 2.2, this is larger than the $\sigma$ used by Stier et al. (2005, $\sigma=2.0$ ). The larger geometric standard deviation is chosen as it reduces the bias in sea spray concentrations in coastal regions, because the wider mode increases the rate of deposition due to both dry deposition and sedimentation. The faster deposition leads to more realistic gradients in sea salt concentrations in coastal regions and improves comparison to observations.

Table 4 summarises the budget of the bulk species compared to other studies. The simulated burdens in GMXe are within the range of the other models, with a simulated burden (in Tg) of 0.20 (BC), 1.71 (POM), $13.04(\mathrm{Du})$ and 6.03 (SS). The $\mathrm{BC}$ burden is larger than that simulated in Stier et al. (2005), probably due to the assumption of 5 monolayers for the conversion of aerosol from hydrophobic to hydrophilic (cf., one monolayer in Stier et al., 2005), but it is closer to the AEROCOM medium value. The sea spray burden is towards the lower end of the range of AEROCOM estimates, but despite this the model tends to overestimate compared to observations.
Table 4. Budget of the bulk species compared to values reported for the M7 within the ECHAM-HAM model (Stier et al., 2005) and the AEROCOM multi-model inter-comparison (Textor et al., 2006). The standard deviation of reported AEROCOM values is given in brackets.

\begin{tabular}{|c|c|c|c|c|}
\hline $\begin{array}{l}\text { Bulk } \\
\text { Species }\end{array}$ & $\begin{array}{l}\text { GMXe } \\
\text { ISOR- } \\
\text { ROPIA-II }\end{array}$ & $\begin{array}{l}\text { GMXe } \\
\text { EQSAM3 }\end{array}$ & $\begin{array}{l}\text { Stier } \\
\text { et al. } \\
(2005)\end{array}$ & $\begin{array}{r}\text { AEROCOM A } \\
\text { (St. Dev.) } \\
(\%)\end{array}$ \\
\hline $\mathrm{BC}$ & 0.20 & 0.20 & 0.11 & $0.24(42)$ \\
\hline $\mathrm{POM}^{\mathrm{a}}$ & 1.71 & 1.73 & 0.99 & $1.70(27)$ \\
\hline DU & 13.04 & 12.94 & 8.28 & $19.2(40)$ \\
\hline SS & 6.03 & 5.67 & 10.50 & $7.52(54)$ \\
\hline
\end{tabular}
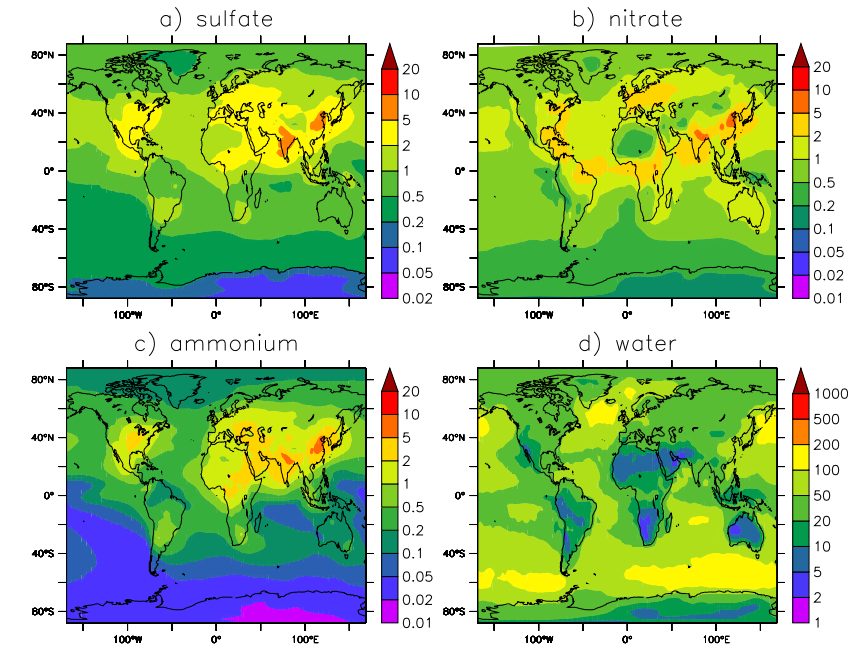

Fig. 7. Annual mean column tropospheric burden of the total concentration of (a) sulfate, (b) nitrate, (c) ammonium and (d) water. All units are in $\mathrm{mg} \mathrm{m}^{-2}$.

\subsubsection{Sulfate, ammonium and nitrate}

Figure 7 shows the tropospheric column burden of the sulfate, ammonium and nitrate aerosol. High concentrations $\left(>1 \mathrm{mg}\left(\mathrm{SO}_{4}\right) \mathrm{m}^{-2}\right)$ of sulfate aerosol occur over most continental regions in the Northern Hemisphere, apart from the less populated regions north of $50^{\circ} \mathrm{N}$, with concentrations of $\left.>2 \mathrm{mg}\left(\mathrm{SO}_{4}\right) \mathrm{m}^{-2}\right)$ also common. The sulfate column burden is at a maximum $\left(>5 \mathrm{mg}\left(\mathrm{SO}_{4}\right) \mathrm{m}^{-2}\right)$ over India and eastern China. The column burden of sulfate is generally $\geq 0.2 \mathrm{mg}\left(\mathrm{SO}_{4}\right) \mathrm{m}^{-2}$, even over the remote ocean, arising from the assumption that $5 \%$ of the sea spray mass flux is sulfate. The burden of ammonium aerosol is largely restricted to continental regions with values of $\geq 1 \mathrm{mg}\left(\mathrm{NH}_{4}\right) \mathrm{m}^{-2}$ over most polluted continental regions, reducing to $0.2-$ $1 \mathrm{mg}\left(\mathrm{NH}_{4}\right) \mathrm{m}^{-2}$ in the $\mathrm{N}$ Atlantic and other polluted marine regions. 
Table 5. Comparison of burdens with other studies. As $\mathrm{HNO}_{3}$ concentrations above the troposphere contribute significantly to the global burden, tropospheric only burdens are given in brackets. For GMXe the tropospheric value is defined as the burden in all model layers with at pressure $>150 \mathrm{hPa}$. ${ }^{\mathrm{a}} \mathrm{EMAC}$ only reports the sum of the gas + aerosol phase wet deposition, thus value for e.g. $\mathrm{NH}_{4}{ }^{+}$is the wet deposition of ammonia + ammonium (same for $\mathrm{HNO}_{3}$ and $\mathrm{H}_{2} \mathrm{SO}_{4}$ ). All units are $\mathrm{Tg} \mathrm{N}$ (or S) $\mathrm{yr}^{-1}$.

\begin{tabular}{|c|c|c|c|c|c|c|c|}
\hline & $\begin{array}{c}\text { GMXe } \\
\text { ISORROPIA-II }\end{array}$ & $\begin{array}{c}\text { GMXe } \\
\text { EQSAM3 }\end{array}$ & $\begin{array}{l}\text { Pye } \\
\text { et al. } \\
(2009)\end{array}$ & $\begin{array}{l}\text { Bauer } \\
\text { et al. } \\
(2007)\end{array}$ & $\begin{array}{c}\text { Feng and } \\
\text { Penner } \\
(2007)\end{array}$ & $\begin{array}{c}\text { Rodriguez } \\
\text { Dabdub } \\
\text { (2004) }\end{array}$ & $\begin{array}{l}\text { Liao } \\
\text { et al. } \\
(2003)\end{array}$ \\
\hline \multicolumn{8}{|c|}{ Emissions } \\
\hline $\mathrm{SO}_{2}$ & 97.9 & 97.9 & 72.5 & 83.9 & & 66.05 & \\
\hline $\mathrm{NH}_{3}$ & 50.85 & 50.85 & 55.0 & 54.1 & 54.1 & 52.08 & \\
\hline NOx & 43.40 & 43.40 & 33.4 & 46.2 & 38.9 & 34.73 & 40.0 \\
\hline \multicolumn{8}{|l|}{ Burden } \\
\hline $\mathrm{SO}_{2}$ & 0.55 & 0.55 & & 0.48 & & 0.204 & \\
\hline $\mathrm{SO}_{4}^{2-}$ & 0.53 & 0.51 & 0.28 & 0.56 & & 0.703 & \\
\hline $\mathrm{NH}_{3}$ & 0.16 & 0.19 & & 0.17 & 0.084 & 0.192 & 0.19 \\
\hline $\mathrm{NH}_{4}^{+}$ & 0.21 & 0.20 & 0.24 & 0.27 & 0.29 & 0.045 & 0.26 \\
\hline $\mathrm{HNO}_{3}$ & $1.28(0.55)$ & $1.29(0.58)$ & & 3.88 & $(0.37)$ & $(0.958)$ & $(0.28)$ \\
\hline $\mathrm{NO}_{3}{ }^{-}$ & 0.13 & 0.11 & 0.35 & 0.52 & 0.16 & 0.417 & 0.18 \\
\hline \multicolumn{8}{|c|}{ Wet Deposition } \\
\hline $\mathrm{SO}_{2}$ & & & & & & 5.08 & \\
\hline $\mathrm{SO}_{4}{ }^{2-}$ & $55.69^{\mathrm{a}}$ & $53.87^{\mathrm{a}}$ & 28.7 & & & 51.69 & \\
\hline $\mathrm{NH}_{3}$ & & & & & 13.1 & 16.7 & \\
\hline $\mathrm{NH}_{4}{ }^{+}$ & $22.12^{\mathrm{a}}$ & $22.35^{\mathrm{a}}$ & 21.1 & & 23.0 & 4.32 & \\
\hline $\mathrm{HNO}_{3}$ & & & & & 16.9 & 3.97 & 8.4 \\
\hline $\mathrm{NO}_{3}{ }^{-}$ & $24.79^{\mathrm{a}}$ & $24.46^{\mathrm{a}}$ & 13.7 & & 8.6 & 18.69 & 5.9 \\
\hline \multicolumn{8}{|c|}{ Dry Deposition } \\
\hline $\mathrm{SO}_{2}$ & 34.42 & 34.36 & & & & 33.02 & \\
\hline $\mathrm{SO}_{4}{ }^{2-}$ & 4.86 & 4.86 & & & & 4.52 & \\
\hline $\mathrm{NH}_{3}$ & 19.14 & 19.48 & & & 15.4 & 29.35 & \\
\hline $\mathrm{NH}_{4}+$ & 0.65 & 0.63 & & & 2.8 & 0.2 & \\
\hline $\mathrm{HNO}_{3}$ & 24.37 & 26.12 & & & 7.5 & 3.97 & 6.3 \\
\hline $\mathrm{NO}_{3}{ }^{-}$ & 1.78 & 1.73 & & & 3.0 & 1.11 & 7.7 \\
\hline
\end{tabular}

The horizontal distribution of nitrate is generally similar to that of sulfate; nitrate is of a similar magnitude to sulfate in many polluted regions (e.g. East Asia, India and the east of North America), and it is at a maximum $\left(>5 \mathrm{mg}\left(\mathrm{NO}_{3}\right) \mathrm{m}^{-2}\right)$ in the regions of India and eastern China where sulfate concentrations are also high.

Table 5 summarises the budget of the sulfate/nitrate/ ammonium system in GMXe and compares it to that of other works which have treated nitrate. The first thing to note is that there is a large range in published burdens of aerosol, this can arise from the range in the treatments of the aerosol distribution e.g. if nitrate formation is permitted in the coarse mode, or if equilibrium is assumed, from different treatments of wet/dry deposition, and from different representations of gas-phase precursors and $\mathrm{NO}_{\mathrm{x}}$ emissions. The burden of sulfate and ammonia simulated with GMXe falls within the range of other models, however the simulated nitrate burden of $0.13 \mathrm{Tg}(\mathrm{N})$ of $\mathrm{NO}_{3}$ is a little below the range of other models $(0.16-0.52 \mathrm{Tg}(\mathrm{N}))$.
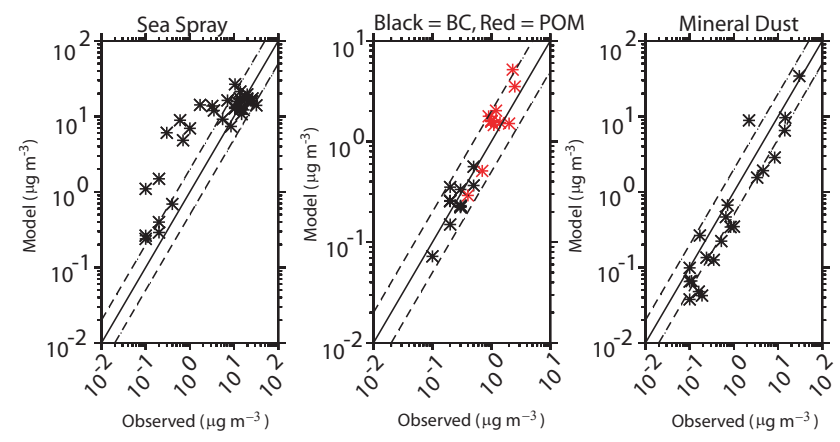

Fig. 8. Annual mean aerosol concentrations compared to the measurements. Measurements of sea salt are from IMPROVE and University of Miami networks, dust from the university of Miami network and $\mathrm{BC}$ and POM from IMPROVE. Units are $\mu \mathrm{g} \mathrm{m}^{-3}$. 

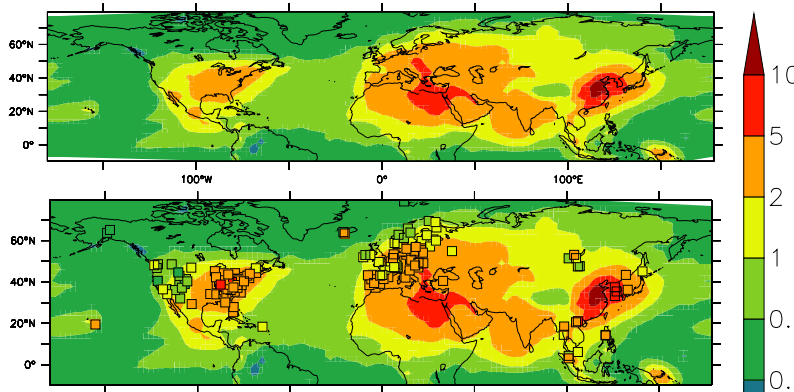

$100^{\circ} \mathrm{W}$ $100^{\circ} \mathrm{E}$

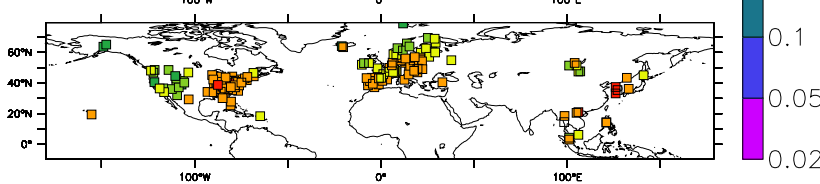

Fig. 9. (a) Top panel: simulated annual mean concentration of sulfate aerosol $\left(\mu \mathrm{g}\left(\mathrm{SO}_{4}{ }^{2-}\right) \mathrm{m}^{-3}\right)$ for the year 2001. (b) Same as (a) but with observations from the CASTNET, EMEP and EANET networks over-plotted. Panel (c) shows the observations alone.

\subsection{Comparison of simulated sulfate, nitrate and ammonium concentrations to large-scale observation networks}

To evaluate the simulated concentrations of sulfate, nitrate and ammonium we compare to data gathered from a number of large-scale monitoring networks. In this first section modelled concentrations are compared to observational data taken from the European Monitoring and Evaluation Programme network (EMEP), Clean Air Status and Trends NETwork (CASTNET, in North America), Interagency Monitoring of PROtected Visual Environments (IMPROVE, North America) and Acid Deposition Monitoring Network in East Asia (EANET). These networks combined give a reasonable coverage of some of the most populated regions in the Northern Hemisphere.

The details of the evaluation are discussed in the following section. In the following section both the observations and the model results are from the years 2001 and 2002.

Figures 9 to 11 show the annual average surface concentration of sulfate, ammonium and nitrate in the Northern Hemisphere for the year 2001. The top panel shows the model data only and in the middle and lower panels the average observation data for that year (2001) are over-plotted. The comparison to the continental observations is summarised in Fig. 12, which shows annual mean values for each simulation year (2001 to 2002) plotted against point observations for that year. The dotted lines are the 1:2 and 2:1 lines. Table 6 summarises the bias between the model and the observations from the large scale monitoring networks.
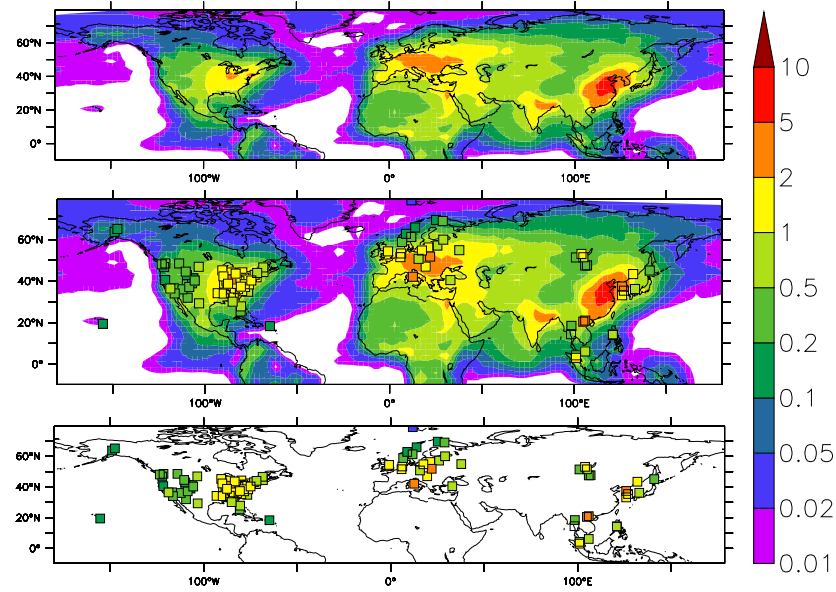

Fig. 10. Same as Fig. 9 but for ammonium aerosol $\left(\mu \mathrm{g}\left(\mathrm{NH}_{4}^{+}\right) \mathrm{m}^{-3}\right)$.
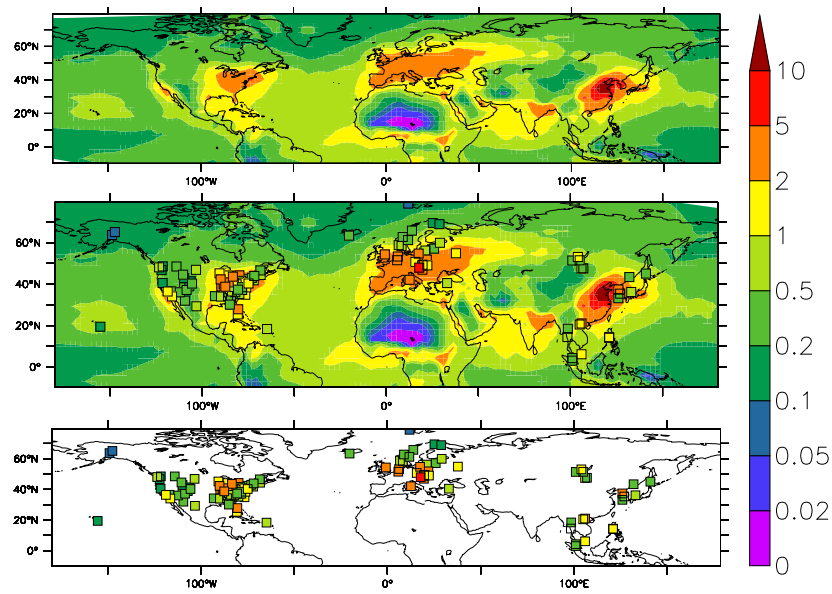

Fig. 11. Same as Fig. 9 but for nitrate aerosol $\left(\mu \mathrm{g}\left(\mathrm{NO}_{3}{ }^{2-}\right) \mathrm{m}^{-3}\right)$.

\subsubsection{Sulfate}

In general the model captures the distribution and magnitude of the sulfate concentration well; the maxima occur over the highly populated regions of each continent, regions which are well known to have high aerosol loading. Sulfate has a high concentration also over the Mediterranean and Saudi Arabia, much of this sulfate arises from export from Europe where emission of $\mathrm{SO}_{2}$ is high. Stier et al. (2005) note that the dry deposition velocity of $\mathrm{SO}_{2}$ may be underestimated (compared to other studies) by the dry deposition scheme of Ganzeveld et al. (1998) that is used (in different implementations) in both ECHAM-HAM and GMXe, thus the modelled burden of sulfate in this region may be overestimated.

Overall, sulfate concentrations are predicted within a factor of two of the observations $85.1 \%$ (and $68.0 \%$ ) of the time compared to CASTNET (and IMPROVE) and $82.7 \%$ compared to the EMEP network. The East Asian region is less 

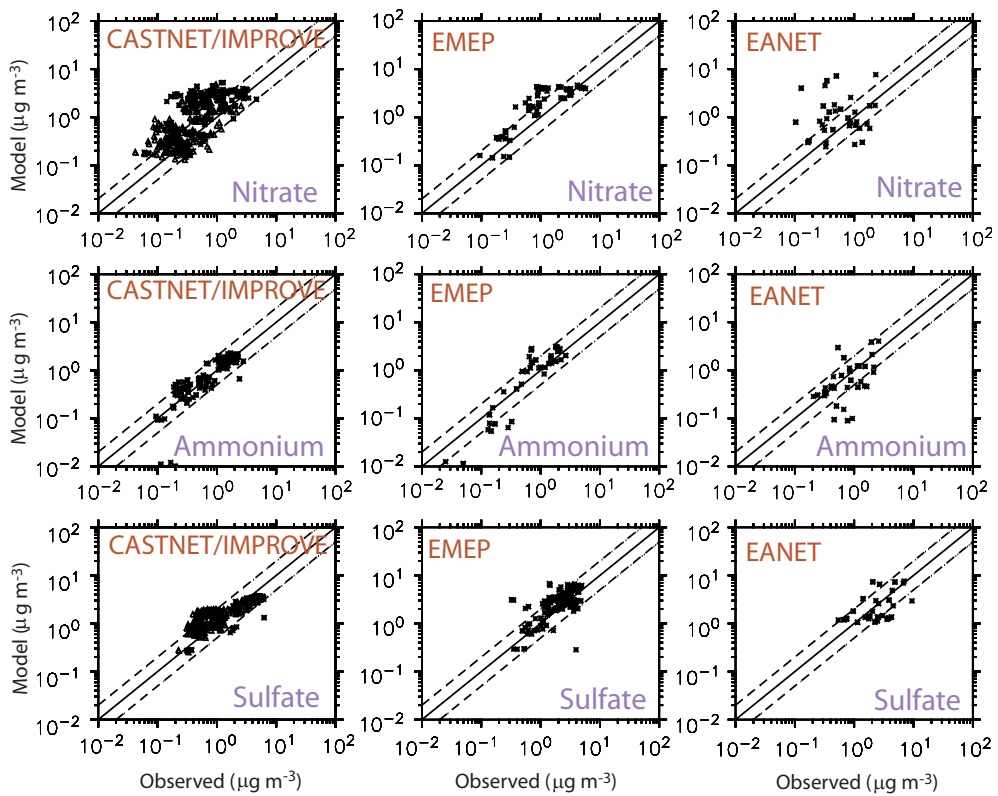

Fig. 12. Observed and modelled (with ISORROPIA-II) annual average concentrations (in $\mu \mathrm{g} \mathrm{m}^{-3}$ ) for the year 2001 of nitrate (top row), ammonium (middle) and sulfate (lowest row) compared to observational data. Left column: CASTNET (star) and IMPROVE (triangle); middle column: EMEP; right column: EANET. Dashed lines indicate the 1:2 and 2:1 ratios.

Table 6. Summary of the comparison of model data to observations taken from the EMEP (Europe), CASTNET (North America) and EANET (Asia) networks (simulations performed using ISORROPIA-II and EQSAM3 are shown). AMR is the arithmetic mean of the modelled values/the arithmetic mean of the observed values; GMR is the geometric mean of the modelled values/the geometric mean of the observed values; PF2 = Percentage of modelled points within a factor of two of the observations.

\begin{tabular}{llcccccc}
\hline & & \multicolumn{3}{c}{ GMXe-ISORROPIA } & \multicolumn{3}{c}{ GMXe-EQSAM3 } \\
Site & Species & AMR & GMR & PF2 & AMR & GMR & PF2 \\
\hline CASTNET & $\mathrm{SO}_{4}{ }^{2-}$ & 0.81 & 0.92 & 85.1 & 0.79 & 0.89 & 91.2 \\
CASTNET & $\mathrm{NH}_{4}{ }^{+}$ & 1.02 & 1.01 & 92.4 & 0.72 & 0.80 & 91.1 \\
CASTNET & $\mathrm{NO}_{3}{ }^{-}$ & 2.11 & 2.28 & 43.7 & 0.93 & 1.17 & 55.0 \\
IMPROVE & $\mathrm{SO}_{4}{ }^{-}$ & 1.26 & 1.48 & 68.0 & 1.17 & 1.41 & 70.9 \\
IMPROVE & $\mathrm{NO}_{3}{ }^{-}$ & 2.29 & 2.01 & 43.7 & 1.49 & 1.49 & 53.4 \\
EMEP & $\mathrm{SO}_{4}{ }^{2-}$ & 1.25 & 1.19 & 82.7 & 1.24 & 1.18 & 82.7 \\
EMEP & $\mathrm{NH}_{4}{ }^{+}$ & 1.31 & 1.01 & 68.4 & 0.90 & 0.69 & 68.4 \\
EMEP & $\mathrm{NO}_{3}{ }^{-}$ & 1.47 & 1.66 & 50.0 & 0.67 & 0.91 & 73.1 \\
EANET & $\mathrm{SO}_{4}{ }^{-}$ & 1.16 & 1.06 & 64.7 & 1.13 & 1.01 & 58.8 \\
EANET & $\mathrm{NH}_{4}{ }^{+}$ & 1.21 & 0.90 & 58.8 & 0.92 & 0.83 & 76.5 \\
EANET & $\mathrm{NO}_{3}{ }^{-}$ & 2.76 & 2.55 & 41.2 & 1.43 & 1.58 & 52.9 \\
\hline
\end{tabular}

well captured with $64.7 \%$ of predictions within a factor of 2 of observations. This is expected to be related to the large uncertainties in emission estimates in the region.

\subsubsection{Ammonium}

The distribution of ammonium aerosol is concentrated in continental regions where concentrations of ammonia are high, e.g. China and India (Clarisse et al., 2009) and where there is an abundant supply of acidic gases (e.g. $\mathrm{H}_{2} \mathrm{SO}_{4}$ and $\mathrm{HNO}_{3}$ ). Ammonium concentrations show very good com- parison to observations in North America with both model and observations predicting values of $0.1-1.0 \mu \mathrm{g}\left(\mathrm{NH}_{4}\right) \mathrm{m}^{-3}$ in the west of the country and $\geq 1.0 \mu \mathrm{g}\left(\mathrm{NH}_{4}\right) \mathrm{m}^{-3}$ in the east. European concentrations are slightly over predicted in eastern Europe and under-predicted in remote sites (e.g. coastal sites in Norway), but otherwise E. Asian and European values are well simulated. This is particularly clear in Fig. 12 which shows that ammonium concentrations are captured well in all three regions, with no particular high or low bias (PF2 $=92.4,68.4$ and $58.8 \%$ for CASTNET, EMEP and EANET, respectively). 


\subsubsection{Nitrate}

Like sulfate, nitrate concentrations peak in the populated regions of North America, Europe and Asia where precursor emissions are high, but elevated nitrate concentrations are also found in coastal regions close to the populated regions. This happens because in inland continental regions the formation of aerosol nitrate is limited by the availability of ammonium. As ammonium sulfate is formed preferentially over ammonium nitrate, the latter only forms in inland regions if there is excess cations e.g. ammonia or the cations present in mineral dust available after all the sulfate has been neutralised. This is not the case in coastal and marine regions where nitrate can enter the aerosol phase using sodium (and not ammonium) as a corresponding cation, resulting in the expulsion of $\mathrm{HCl}$ and facilitating the formation of aerosol nitrate. Thus concentrations of nitrate in coastal regions can be significant (e.g. Yeatman et al., 2001).

Nitrate concentrations in Europe are reasonably well captured but in North America there is an overestimation of nitrate compared to observations (by approximately a factor of 2.0). Part of this overestimation is likely to arise from measurement biases in the IMPROVE and CASTNET data sets. The nitrate concentrations observed by the CASTNET network are known to have a low bias, especially in warm dry conditions, as nitrate can evaporate from the filters when temperatures are high (summarised in Ames and Malm, 2001). The IMPROVE network does not efficiently sample aerosol $>2.5 \mu \mathrm{m}$ aerodynamic diameter due to the inlet type (Ames and Malm, 2001), and thus will underestimate total nitrate, which is particularly important in regions where a large fraction of the nitrate is in the coarse mode.

Although these sampling issues may explain part of the bias, it is likely that GMXe overestimates the concentration of nitrate aerosol in coastal regions because of the overestimation of sea spray aerosol in these regions; the overabundance of sodium results in an overestimation of aerosol nitrate if $\mathrm{HNO}_{3}$ concentrations are significant. The choice of a larger $\sigma$ for the coarse hydrophilic mode (Sect. 4.2.1) reduces the bias in sea salt concentrations and improves the comparison of modelled nitrate to observations in these regions.

An additional possible cause of bias in the simulated nitrate concentrations comes from the concentrations of the gas phase precursors. Estimates of global $\mathrm{NO}_{\mathrm{x}}$ emissions are uncertain (e.g. Konovalov et al., 2008; Han et al., 2009) and these uncertainties (along with uncertainties in the deposition rate of gas phase precursors) add to the potential for biases in the gas phase precursor fields. The simulated fields of $\mathrm{HNO}_{3}$ and NO in ECHAM/MESSy were evaluated in Jöckel et al. (2006) and Tost et al. (2007a) examined the wet deposition of nitrate and found the model simulated deposition fluxes to be in good agreement with observations.

In east Asia, the predicted mean value of nitrate is well captured but there is considerable scatter caused by an overestimation of nitrate concentrations at marine influenced sites
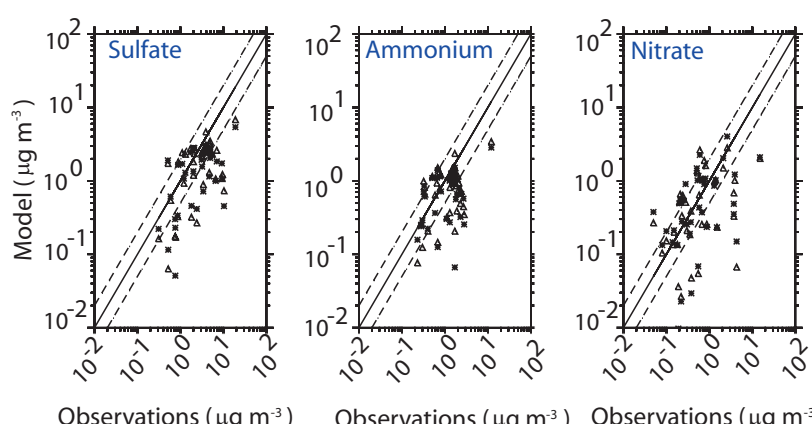

Fig. 13. Simulated concentration of sulfate, ammonium and nitrate aerosol for the year 2001 (star) and 2002 (triangle) compared to AMS data summarised by Zhang et al. (2007).

between China and Japan and an underestimation at some more remote sites. We note that in general the model tends to have difficulties in East Asia, probably due to the complexity of the meteorology and the large uncertainties in the emissions in this region.

\subsection{Aerosol mass spectrometer data}

In addition to long term observational data sets it is also useful to compare to data gathered in short term field campaigns. Zhang et al. (2007) summarised aerosol mass spectrometers (AMS) observations gathered in a range of field campaigns in North America, Europe and East Asia which were performed between 2000 and 2006. In Fig. 13 we compare GMXe fields to this observational database. To capture any seasonal dependence we extract the model data for the months of the different campaigns. As the measurements are of sub-micron mass, in this comparison we consider only the mass that is $<1 \mu \mathrm{m}$ diameter (calculated from the average size of the aerosol at the measurement locations). We use model data representative of 2001 and 2002, although the field campaign data was taken over a range of different years.

Modelled concentrations of all three species are reasonable, in general there is a tendency to underestimate all species, with sulfate captured most poorly $(\mathrm{GMR}=0.47)$. Ammonium and nitrate are captured with less bias (GMR $=0.59$ and 0.52 , respectively). Out of a total of 37 samples $43 \%$ of sulfate, $49 \%$ of ammonium and $41 \%$ of nitrate samples are within a factor of 2 of the measured values.

We note that as the observations span a wider range of years than the simulations the simulated meteorology will not represent the conditions at the time of measurement, thus there may be compensating errors that can not be identified without extending the simulation to span the full measurement time period. In future work GMXe will be used in a longer term simulation where evaluation of this kind will be possible. 

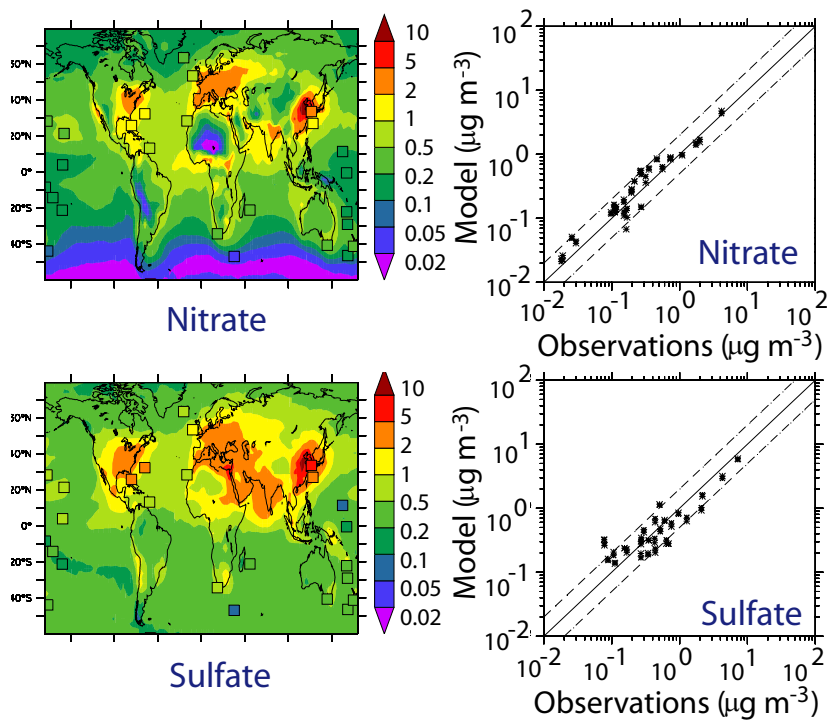

Sulfate
Fig. 14. Comparison of modelled data to data collected by AEROCE. Maps show surface concentrations of nitrate (top) and sulfate (bottom) for the year 2002 simulated using ISORROPIA-II with observed values overplotted (squares). Scatter plots show the comparison of modelled vales to AEROCE data for nitrate (top) and sulfate (bottom) for the year 2001 (triangles) and 2002 (stars). All units are $\mu \mathrm{g} \mathrm{m}^{-3}$.

\subsection{Marine regions: AEROCE data}

The AEROCOM inter-comparison project has made available data from the Atmosphere/Ocean Chemistry Experiment (AEROCE), SEAREX and DOE projects (J. Prospero, personal communication, 2009, for an overview see: http:// www.igac.noaa.gov/newsletter/24/aeroce.php). The data set consists of measurement data taken from remote marine regions during the 1980s and 1990s. These data are multiannual data which have been averaged to provide a climatology of marine aerosol observations. In Fig. 14 we show comparison of simulated concentrations of sulfate and nitrate compared to the observed data. The sulfate data observed is reported as non-sea salt sulfate but we compare to total sulfate simulated by the model, thus simulated concentrations may be biased high.

Both the distribution and the magnitude of the observed values are captured well by the model; $\mathrm{PF} 2=82 \%$ for sulfate and $96 \%$ of nitrate, with a GMR of 1.01 and 1.21 , respectively. The good agreement between simulated and observed nitrate implies that the partitioning of $\mathrm{HNO}_{3}$ to the sea spray aerosol is well represented in the model. Sulfate values are well simulated at polluted sites but are overestimated in very remote marine regions. As the geographical distribution of sulfate precursor emissions has changed significantly since the 1980 s, a perfect agreement between model and observations is not expected, however, this change in the distribution of emissions is less important for remote marine locations where the AEROCE data is concentrated.

\subsection{Aerosol optical depth}

Aerosol optical depth (AOD) is a useful diagnostic for validating global and regional aerosol models as not only it is one of the most important diagnostics for climate forcing, but it is also relatively easy to evaluate as both local and global measurements of AOD are available. A new submodel is currently being developed for use in the EMAC model (AEROPT), this submodel will calculate AOD in a sophisticated manner, once complete it is a straightforward task to couple the aerosol fields simulated with GMXe to the new submodel. However, development and evaluation of AOD parametrisation scheme is a non-trivial task and the submodel is not yet fully developed.

For evaluation purposes, we use a simplified treatment of AOD, based on the parametrisation of Kiehl and Briegleb (1993):

$\operatorname{AOD}(\lambda)=f(\mathrm{RH}, \lambda) B(\lambda) \alpha$

where $\operatorname{AOD}(\lambda)$ is the optical depth at the reference wavelength $(\lambda)$ and $B(\lambda)$ is the mass extinction coefficient $\left(\mathrm{m}^{2} \mathrm{~g}^{-2}\right)$. For the latter, we take mean values of 5 for sulfate, nitrate and ammonium (Jeuken et al., 2001); 9 for BC; and 4 for POM (Liousse et al., 1996) and 3 for sea spray (Kinne et al., 2006). The effect of variations in relative humidity $(\mathrm{RH})$ on AOD is taken into account in the term $f(\mathrm{RH}, \lambda)$, we approximate this effect using the parametrisation of Veefkind (1999); Tsigaridis et al. (2005), which relates $f(\mathrm{RH}, \lambda)$ to RH using a polynomial fit which they derived from observational data. This calculation of AOD is taken from Jeuken et al. (2001); Tsigaridis et al. (2005, 2006). Although we acknowledge that this is a simplified treatment of aerosol optical depth, it should suffice for a first evaluation with remotely-sensed AOD values. A more detailed analysis of aerosol optical depth simulated with GMXe will be presented in future work.

Figure 15 shows the simulated annual mean aerosol optical depth, with the annual mean values measured by AERONET (sun photometer data, $550 \mathrm{~nm}$ Holben et al., 2001) overplotted in the squares. Also shown is the AOD measured by the MODIS instrument $(550 \mathrm{~nm}$, level 2 data). The model captures both the magnitude and the distribution of AOD fairly well, in both North and South America most values are well captured, although there are regional maxima, for example in the west of South America that are not captured. European and North American AOD values are well simulated, except for the large observed AOD event in Mexico which the model fails to capture. There is also a very low AOD observed by AERONET in eastern Russia that the model overestimates significantly. Compared to MODIS AOD, GMXe tends to underestimate marine AOD values; MODIS observes AOD between $0.1-0.15$ in almost all remote marine regions, but GMXe tends to simulate between $0.05-0.15$. 


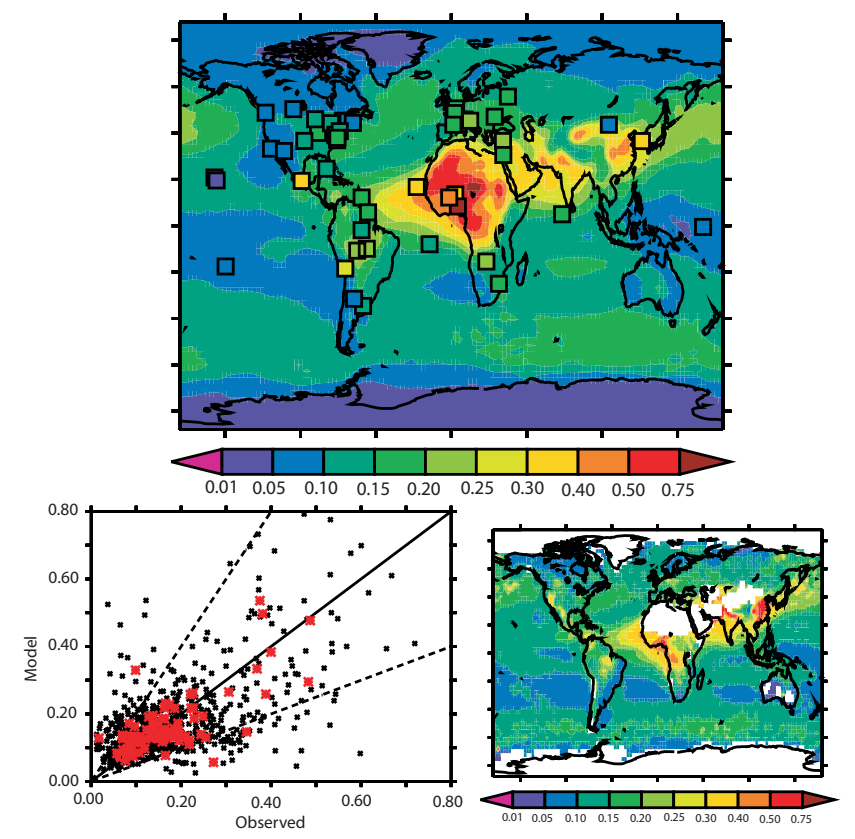

Fig. 15. (a) Annual mean AOD modelled with GMXe for the year 2001, over-plotted are annual mean measurements from the AERONET network (2001), (b) summary of the comparison between GMXe and AERONET, black points are monthly mean and red are annual mean $\left(r^{2}=0.51\right)$. (c) Annual mean AOD from MODIS for 2001.

The scatter plot shows that most $(92 \%)$ simulated AOD values are within a factor of two of the AERONET observations, however despite the generally good agreement with observations there is still a lot of scatter in the comparison, particularaly in the monthly mean data, this implies that the seasonal cycle of the AOD may not always be well captured. This will be investigated further with the AEROPT submodel, when the submodel development is complete.

\subsection{Sensitivity to the choice of partitioning model}

The model framework of GMXe allows the user to choose between two gas/aerosol partitioning schemes. In all the discussion so far the ISORROPIA-II scheme has been used. To demonstrate the sensitivity of the simulated species to the choice of partitioning model, Fig. 16 shows the comparison of fields simulated using the EQSAM3 treatment of partitioning with observations from the CASTNET/EMEP and EANET networks (comparable to Fig. 12 for ISORROPIAII). In addition, Table 6 summarises the bias between model and the large-scale observation networks when EQSAM3 is used.

Nitrate concentrations are most sensitive to the choice of partitioning model; particularly in North America where nitrate loadings are lower using EQSAM3 (and in better agree- ment with observations). East Asian concentrations are still poorly captured, with a smaller high bias $(\mathrm{GMR}=1.58)$, but with a very large amount of scatter. When EQSAM3 is used, GMXe tends to underestimate ammonium concentrations $(\mathrm{GMR}=0.69$ to 0.83$)$ particularly at low concentrations. In contrast ISORROPIA-II, shows no consistent bias in ammonia concentrations (GMR $=0.8-1.01)$. Sulfate concentrations are little affected by the choice of partitioning models as both ISORROPIA-II and EQSAM3 assume that upon condensation sulfate remains in the aerosol phase.

The concentrations of the "bulk" species are also largely insensitive to the choice of partitioning model (Table 4, column 2), this is to be expected as the only changes would come from (i) changes in the particle ageing due to different partitioning of the semi-volatile species on the bulk species, or (ii) changes in aerosol water uptake. The sensitivity of the simulated aerosol water to the choice of partitioning models is summarised in Table 7, which shows the calculated annual mean hygroscopic growth factor $(\mathrm{GF}=$ wet radius/dry radius) for each mode. The GF of the different modes reflects the change in composition with size: the Aitken mode has a large percentage mass of hydrophobic BC and POM (as this is the size where these species are emitted) and thus has the lowest GF. BC/POM are less dominant in the accumulation mode as condensed sulfate and nitrate and primary sea spray aerosol add mass (reducing the hydrophobic mass fraction), thus the GF is larger. The coarse mode has the largest GF as the composition is dominated by the highly hydrophilic sea spray aerosol. Both ISORROPIA-II and EQSAM3 capture this trend in GF and simulate similar global mean GFs (percentage difference $\leq 6 \%$ ). For both ISORROPIA-II and EQSAM3, the global distribution of GF is dominated by the distribution of relative humidity (not shown).

In summary, the choice of partitioning model has a small effect on the distribution of most aerosol species, the exception is nitrate, the concentration of which is generally lower when EQSAM3 is used.

It is not possible from this analysis to state which partitioning scheme is "better" as concentrations of nitrate aerosol are sensitive to many factors in the model e.g. the distribution of bulk aerosol species and the concentration of precursor gases, and biases in these properties may lead to compensating errors in the simulated fields. Thus here we do not attempt to evaluate the partitioning schemes (as this is better done in a box model, e.g. Yu et al., 2005) we only aim to show that that the implementation of ISORROPIA-II and EQSAM3 in GMXe are able to produce realistic distributions of nitrate/sulfate/ammonium and bulk aerosol. Finally, it is worth noting that as implemented within GMXe, both partitioning models have similar CPU times. 

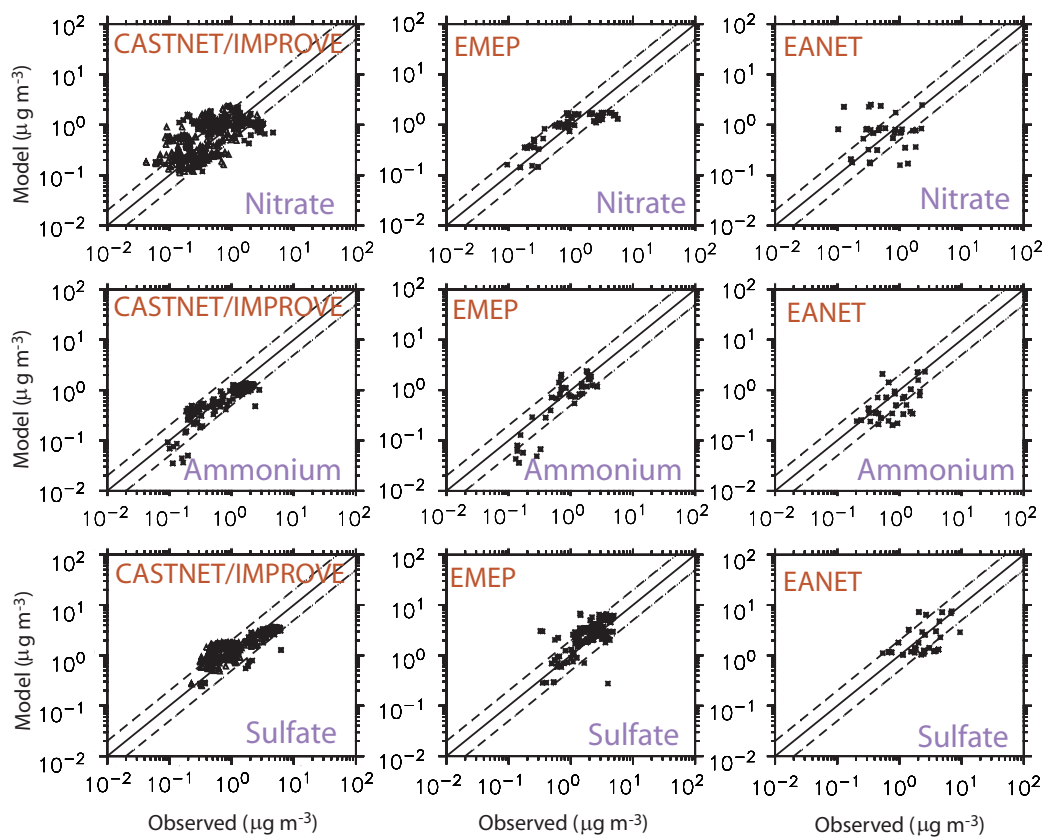

Fig. 16. Observed and modelled (with EQSAM3) annual average concentrations (in $\mu \mathrm{g} \mathrm{m}^{-3}$ ) for the year 2001 of nitrate (top row), ammonium (middle) and sulfate (lowest row) compared to observational data. Left column: CASTNET (star) and IMPROVE (triangle); middle column: EMEP; right column: EANET. Dashed lines indicate the 1:2 and 2:1 ratios.

Table 7. Summary of the annual mean hygroscopic growth factors (GF = wet radius/dry radius) for the simulation using ISORROPIA-II and EQSAM3. Analysis considers (i) the surface layer only and (ii) all vertical levels.

\begin{tabular}{lccccr}
\hline & \multicolumn{2}{c}{ ISORROPIA-II } & \multicolumn{2}{c}{ EQSAM3 } & \\
Mode & Mean & St. Dev. & Mean & St. Dev. & \% Difference \\
\hline Surface & & & & & \\
Aitken & 1.25 & 0.05 & 1.18 & 0.03 & 5.60 \\
Accumulation & 1.67 & 0.18 & 1.70 & 0.18 & -1.80 \\
Coarse & 1.82 & 0.20 & 1.87 & 0.19 & -2.75 \\
Whole atmosphere & & & & & \\
Aitken & 1.26 & 0.08 & 1.20 & 0.05 & 4.76 \\
Accumulation & 1.37 & 0.17 & 1.35 & 0.16 & 1.46 \\
Coarse & 1.48 & 0.25 & 1.46 & 0.24 & 1.35 \\
\hline
\end{tabular}

\section{Conclusions}

This paper has introduced a newly developed aerosol submodel which has been implemented and tested within the EMAC general circulation model. The treatment of aerosol microphysics in the submodel is similar to that of the M7 model (Vignati et al., 2004), but a number of new developments have been made:

- The microphysics code has been extended to allow the simulation of an increased and varied number of aerosol species; in addition to the five species (SS, POM, BC,
$\mathrm{Du}$ and $\mathrm{SO}_{4}{ }^{2-}$ ) treated by $\mathrm{M} 7, \mathrm{GMXe}$ can also treat $\mathrm{NO}_{3}{ }^{-}, \mathrm{NH}_{4}{ }^{+}, \mathrm{Na}^{+}, \mathrm{Cl}^{-}, \mathrm{Ca}^{2+}, \mathrm{Mg}^{2+}, \mathrm{K}^{+}$and potentially more (including organics).

- The treatment of aerosol emissions has been adapted to allow the sub-division of bulk emission streams into speciated emissions, for example sea salt aerosol can now be treated as sodium and chloride etc. This has been done in a flexible manner to allow the user to select their own choice of speciation to allow sensitivity studies to be carried out. 
- The aerosol microphysics has been coupled to a choice of treatments of gas/aerosol partitioning. This framework allows the inter-comparison of the different techniques of gas/aerosol partitioning, within the same aerosol model. Thus sensitivity to the treatment of partitioning can be examined without additional variation due e.g. to different modelling frameworks or treatment of aerosol microphysics.

- The new model is accompanied by a user manual (see the electronic supplement), which gives examples of potential model setups and advice on how to adapt the model to suit the simulation required.

An initial comparison of the modelled fields to other models and to observations has been carried out. The model is able to simulate the bulk aerosol burden and distribution in a manner similar to other established aerosol models, with the burden of the bulk species lying within the range of the AEROCOM models (Textor et al., 2006) and the simulated values showing generally good comparison with observations, except for an overestimation of sea spray concentrations in inland coastal regions.

The simulated fields of sulfate, ammonium and nitrate aerosol have been compared to observations gathered from both polluted and remote regions. In Europe and North America, the model captures continental concentrations of ammonium and sulfate well; $>68 \%$ of modeled values lie within a factor of 2 of the observations. In E. Asia the model simulates realistic values, but the comparison to observations shows a large amount of scatter ( $\mathrm{PF} 2=59 \%)$.

When the ISORROPIA-II gas aerosol partitioning scheme is used, GMXe tends to overestimate nitrate concentrations in polluted regions (GMR $=1.66$ to 2.55 ), but marine concentrations are very well simulated. The overestimation arises, at least in part, from an overestimation of sea spray aerosol in coastal regions, which causes an overestimation of the cation availability. The overestimation in nitrate is less pronounced when the EQSAM3 scheme is used. However, simulated concentrations of ammonium are generally under-predicted. Both schemes are available in the model for future intercomparison studies.

A simple calculation of aerosol optical depth was used to show that GMXe is capable of simulating a reasonable AOD distribution that matches both AERONET (PF2 =92\%) and MODIS observations reasonably well. In the future, a more comprehensive calculation of AOD will be available in EMAC, and thus a fuller analysis of the AOD simulated with GMXe will be carried out.

\section{Supplementary material related to this article is available online at: http://www.geosci-model-dev.net/3/391/2010/ gmd-3-391-2010-supplement.pdf.}

Acknowledgements. The authors are grateful to the IMPROVE, CASTNET, EMEP, EANET and AERONET networks for the useful observation data provided and to Michael Schulz and the AEROCOM team for the work done in collecting observation data together and to Frank Dentener for providing emission data. We also thank the scientists associated with the GAW network for providing aerosol number data. $\mathrm{AN}$ and $\mathrm{CF}$ acknowledge support from the National Oceanic and Atmospheric Administration grant number NMRAC000-5-04017. SM is grateful for the financial support through the CIRCE Integrated Project (http://www.circeproject.eu/) of the European Commission's Sixth Framework Program, project number 036961.

Also many thanks to staff at the MPI for Chemistry for help with the EMAC model, especially Patrick Jöckel, Astid Kerkweg and Andreas Baumgärtner. Finally, thanks to Laurens Ganzeveld for helpful information and advice on the deposition routines.

The service charges for this open access publication have been covered by the Max Planck Society.

Edited by: Olivier Boucher

\section{References}

Adams, P. J., Seinfeld, J. H., and Koch, D. M.: Global concentrations of tropospheric sulfate, nitrate, and ammonium aerosol simulated in a general circulation model, J. Geophys. Res.-Atmos., 104, 13791-13824, doi:10.1029/1999JD900083, 1999.

Adams, P. J., Seinfeld, J. H., Koch, D. M., Mickley, L. J., and Jacob, D. J.: General circulation model assessment of direct radiative forcing by the sulfate-nitrate-ammonium-water inorganic aerosol system, J. Geophys. Res.-Atmos., 106, 1097-1111, 2001.

Ames, R. B. and Malm, W. C.: Comparison of sulfate and nitrate particle mass concentrations measured by IMPROVE and the CDN, Atmos. Environ., 35, 905-916, 2001.

Andreae, M. O.: Correlation between cloud condensation nuclei concentration and aerosol optical thickness in remote and polluted regions, Atmos. Chem. Phys., 9, 543-556, doi:10.5194/acp-9-543-2009, 2009.

Bauer, S. E. and Koch, D.: Impact of heterogeneous sulfate formation at mineral dust surfaces on aerosol loads and radiative forcing in the Goddard Institute for Space Studies general circulation model, J. Geophys. Res.-Atmos., 110, D17202, doi:10.1029/2005JD005870, 2005.

Bauer, S. E., Koch, D., Unger, N., Metzger, S. M., Shindell, D. T., and Streets, D. G.: Nitrate aerosols today and in 2030: a global simulation including aerosols and tropospheric ozone, J. Geophys. Res.-Atmos., 7, 5043-5059, 2007.

Capaldo, K., Pilinis, C., and Pandis, S. N.: A computationally efficient hybrid approach for dynamic gas/aerosol transfer in air quality models, Atmos. Environ., 34, 3617-3627, 2000.

Castro, P. and Huber, M. E.: Marine Biology, McGraw-Hill, 2003.

Clarisse, L., Clerbaux, C., Dentener, F. Hurtmans, D., and Coheur, P.-F.: Global ammonia distribution derived from infrared satellite observations, Nat. Geosci., 2, 479-483, 2009.

Dentener, F., Kinne, S., Bond, T., Boucher, O., Cofala, J., Generoso, S., Ginoux, P., Gong, S., Hoelzemann, J. J., Ito, A., Marelli, L., Penner, J. E., Putaud, J.-P., Textor, C., Schulz, M., van der Werf, G. R., and Wilson, J.: Emissions of primary aerosol and pre- 
cursor gases in the years 2000 and 1750 prescribed data-sets for AeroCom, Atmos. Chem. Phys., 6, 4321-4344, doi:10.5194/acp6-4321-2006, 2006.

Derwent, R., Collins, W., Jenkin, M., Johnson, C., and Stevenson, D.: The Global Distribution of Secondary Particulate Matter in a 3-D Lagrangian Chemistry Transport Model, J. Atmos. Chem., 44, 57-95, 2003.

Feng, Y. and Penner, Y.: Global modeling of nitrate and ammonium: Interaction of aerosols and tropospheric chemistry, J. Geophys. Res.-Atmos., 112, doi:10.1029/2005JD006404, 2007.

Forster, P., Ramaswamy, V., Artaxo, P., Berntsen, T., Betts, R., Fahey, D., Haywood, J., Lean, J., Lowe, D., Myhre, G., Nganga, J., Prinn, R., Raga, G., M., S., and Dorland, R. V.: Integovernmental Panel on Climate Change, chap. Changes in Atmospheric Constituents and in Radiative Forcing, Cambridge University Press, Cambridge, United Kingdom and New York, NY, USA, 2007.

Fountoukis, C. and Nenes, A.: ISORROPIA II: a computationally efficient thermodynamic equilibrium model for $\mathrm{K}^{+}-\mathrm{Ca}^{2+}$ $-\mathrm{Mg}^{2+}-\mathrm{NH}_{4}^{+}-\mathrm{Na}^{+}-\mathrm{SO}_{4}^{2-}-\mathrm{NO}_{3}^{-}-\mathrm{Cl}^{-}-\mathrm{H}_{2} \mathrm{O}$ aerosols, Atmos. Chem. Phys., 7, 4639-4659, doi:10.5194/acp-7-4639-2007, 2007.

Fountoukis, C., Nenes, A., Sullivan, A., Weber, R., Van Reken, T., Fischer, M., Matías, E., Moya, M., Farmer, D., and Cohen, R. C.: Thermodynamic characterization of Mexico City aerosol during MILAGRO 2006, Atmos. Chem. Phys., 9, 2141-2156, doi:10.5194/acp-9-2141-2009, 2009.

Fuchs, N.: Evaporation and droplet growth in gaseous media, Pergamon Press, 1959.

Fuchs, N.: The Mechanics of aerosols, Pergamon Press, 1964.

Ganzeveld, L. and Lelieveld, J.: Dry deposition parametrization in a chemistry general circulation model and its influence on the distribution of reactive trace gases, J. Geophys. Res.-Atmos., 100, 20999-21012, 1995.

Ganzeveld, L., Lelieveld, J., and Roelofs, G.: A dry deposition parameterization for sulfur oxides in a chemistry and general circulation model, J. Geophys. Res.-Atmos., 103, 5679-5694, doi:10.1029/97JD03077, 1998.

Gerber, H. E.: Supersaturation and Droplet Sectral Evolution in Fog, J. Atmos. Sci., 48, 2569-2588, 1991.

Ginoux, P., Chin, M., Tegen, I., Prospero, J. M., Holben, B. N., Dubovik, O., and Lin, S. J.: Sources and distribution of dust aerosols with the GOCART model, J. Geophys. Res.-Atmos., 106, 20255-20273, 2001.

Ginoux, P., Prospero, J. M., Torres, O., and Chin, M.: Long-term simulation of global dust distribution with the GOCART model: Correlation with the North Atlantic Oscillation, Environ. Modell. Softw., 19, 113-128, doi:10.1016/S1364-8152(03)00114-2, 2003.

Gong, S.: A parameterization of sea-salt aerosol source function for sub- and super-micron particles, Global Biogeochem. Cy., 17, 1097-1103, 2003.

Granat, L., Engström, J. E., Praveen, S., and Rodhe, H.: Light absorbing material (soot) in rainwater and in aerosol particles in the Maldives, J. Geophys. Res.-Atmos., 115, D16307, doi:10.1029/2009JD013768, 2010.

Han, K. M., Song, C. H., Ahn, H. J., Park, R. S., Woo, J. H., Lee, C. K., Richter, A., Burrows, J. P., Kim, J. Y., and Hong, J. $\mathrm{H}$.: Investigation of $\mathrm{NO}_{\mathrm{x}}$ emissions and $\mathrm{NO}_{\mathrm{x}}$-related chemistry in East Asia using CMAQ-predicted and GOME-derived NO2 columns, Atmos. Chem. Phys., 9, 1017-1036, doi:10.5194/acp9-1017-2009, 2009.

Hanisch, F. and Crowley, J. N.: Heterogeneous reactivity of NO and HNO3 on mineral dust in the presence of ozone, Phys. Chem. Chem. Phys., 5, 883-887, doi:10.1039/B211503D, 2003.

Hofmeister, F.: Zur Lehre von der Wirkung der Salze, Arch. Exp. Pathol. Pharmakol, (Leipzig) 24 (1888) 247-260; translated in: Zur Lehre von der Wirkung der Salze (about the science of the effect of salts: Franz Hofmeisters historical papers, Curr. Opin. Coll. Interface (2004), 19-37, 1888.

Holben, B. N., Tanré, D., Smirnov, A., Eck, T. F., Slutsker, I., Abuhassan, N., Newcomb, W. W., Schafer, J. S., Chatenet, B., Lavenu, F., Kaufman, Y. J., Castle, J. V., Setzer, A., Markham, B., Clark, D., Frouin, R., Halthore, R., Karneli, A., O'Neill, N. T., Pietras, C., Pinker, R. T., Voss, K., and Zibordi, G.: An emerging ground-based aerosol climatology: Aerosol optical depth from AERONET, J. Geophys. Res.-Atmos., 106, 1206712098, doi:10.1029/2001JD900014, 2001.

Jacobson, M.: Studying the effects of calcium and magnesium on size-distributed nitrate and ammonium with EQUISOLV II, Atmos. Environ., 33, 3635-3649, 1999.

Jeuken, A., Veefkind, J. P., Dentener, F., Metzger, S., and Gonzalez, C. R.: Simulation of the aerosol optical depth over Europe for August 1997 and a comparison with observations, J. Geophys. Res.-Atmos., 106, 28295-28311, 2001.

Jöckel, P., Sander, R., Kerkweg, A., Tost, H., and Lelieveld, J.: Technical Note: The Modular Earth Submodel System (MESSy) - a new approach towards Earth System Modeling, Atmos. Chem. Phys., 5, 433-444, doi:10.5194/acp-5-433-2005, 2005.

Jöckel, P., Tost, H., Pozzer, A., Brühl, C., Buchholz, J., Ganzeveld, L., Hoor, P., Kerkweg, A., Lawrence, M. G., Sander, R., Steil, B., Stiller, G., Tanarhte, M., Taraborrelli, D., van Aardenne, J., and Lelieveld, J.: The atmospheric chemistry general circulation model ECHAM5/MESSy 1: consistent simulation of ozone from the surface to the mesosphere, Atmos. Chem. Phys., 6, 50675104, doi:10.5194/acp-6-5067-2006, 2006.

Karydis, V. A., Tsimpidi, A. P., Fountoukis, C., Nenes, A., Zavala, M., Lei, W., Molina, L. T., and Pandis, S. N.: Simulating the fine and coarse inorganic particulate matter concentrations in a polluted megacity, Atmos. Environ., 44, 608-620, doi:10.1016/j.atmosenv.2009.11.023, 2010.

Kerkweg, A., Buchholz, J., Ganzeveld, L., Pozzer, A., Tost, H., and Jöckel, P.: Technical Note: An implementation of the dry removal processes DRY DEPosition and SEDImentation in the Modular Earth Submodel System (MESSy), Atmos. Chem. Phys., 6, 4617-4632, doi:10.5194/acp-6-4617-2006, 2006a.

Kerkweg, A., Sander, R., Tost, H., and Jöckel, P.: Technical note: Implementation of prescribed (OFFLEM), calculated (ONLEM), and pseudo-emissions (TNUDGE) of chemical species in the Modular Earth Submodel System (MESSy), Atmos. Chem. Phys., 6, 3603-3609, doi:10.5194/acp-6-3603-2006, $2006 \mathrm{~b}$.

Kerkweg, A., Sander, R., Tost, H., Jöckel, P., and Lelieveld, J.: Technical Note: Simulation of detailed aerosol chemistry on the global scale using MECCA-AERO, Atmos. Chem. Phys., 7, 2973-2985, doi:10.5194/acp-7-2973-2007, 2007.

Kiehl, J. and Briegleb, B. P.: The relative roles of sulfate aerosols and greenhouse gases in climate forcing, Science, 260, 311-314, 1993.

Kinne, S., Schulz, M., Textor, C., Guibert, S., Balkanski, Y., Bauer, 
S. E., Berntsen, T., Berglen, T. F., Boucher, O., Chin, M., Collins, W., Dentener, F., Diehl, T., Easter, R., Feichter, J., Fillmore, D., Ghan, S., Ginoux, P., Gong, S., Grini, A., Hendricks, J., Herzog, M., Horowitz, L., Isaksen, I., Iversen, T., Kirkevåg, A., Kloster, S., Koch, D., Kristjansson, J. E., Krol, M., Lauer, A., Lamarque, J. F., Lesins, G., Liu, X., Lohmann, U., Montanaro, V., Myhre, G., Penner, J., Pitari, G., Reddy, S., Seland, O., Stier, P., Takemura, T., and Tie, X.: An AeroCom initial assessment - optical properties in aerosol component modules of global models, Atmos. Chem. Phys., 6, 1815-1834, doi:10.5194/acp-6-1815-2006, 2006.

Konovalov, I. B., Beekmann, M., Burrows, J. P., and Richter, A.: Satellite measurement based estimates of decadal changes in European nitrogen oxides emissions, Atmos. Chem. Phys., 8, 2623 2641, doi:10.5194/acp-8-2623-2008, 2008.

Kulmala, M., Laaksonen, A., and Pirjola, L.: Parameterization for sulfuric acid/water nucleation rates, J. Geophys. Res.-Atmos., 103, 8301-8307, 1998.

Lauer, A. and Hendricks, J.: Simulating aerosol microphysics with the ECHAM4/MADE GCM - Part II: Results from a first multiannual simulation of the submicrometer aerosol, Atmos. Chem. Phys., 6, 5495-5513, doi:10.5194/acp-6-5495-2006, 2006.

Lauer, A., Hendricks, J., Ackermann, I., Schell, B., Hass, H., and Metzger, S.: Simulating aerosol microphysics with the ECHAM/MADE GCM - Part I: Model description and comparison with observations, Atmos. Chem. Phys., 5, 3251-3276, doi:10.5194/acp-5-3251-2005, 2005.

Liao, H., Adams, P. J., Chung, S. H., Seinfeld, J. H., Mickley, L. J., and Jacob, D. J.: Interactions between tropospheric chemistry and aerosols in a unified general circulation model, J. Geophys. Res.-Atmos., 108(D1), 4001, doi:10.1029/2001JD001260, 2003.

Liousse, C., Penner, J. E., Chuang, C., Walton, J. J., Eddleman, H., and Cachier, H.: A global three-dimensional model study of carbonaceous aerosols, J. Geophys. Res.-Atmos., 101(D14), 19411-19432, doi:10.1029/95JD03426, 1996.

Lohmann, U., Stier, P., Hoose, C., Ferrachat, S., Kloster, S., Roeckner, E., and Zhang, J.: Cloud microphysics and aerosol indirect effects in the global climate model ECHAM5-HAM, Atmos. Chem. Phys., 7, 3425-3446, doi:10.5194/acp-7-3425-2007, 2007.

Malm, W. C., Schichtel, B. A., Pitchford, M. L., Ashbaugh, L. L., and Eldred, R. A.: Spatial and monthly trends in speciated fine particle concentration in the United States, J. Geophys. Res.Atmos., 109, D03306, doi:10.1029/2003JD003739, 2004.

Mann, G. W., Carslaw, K. S., Spracklen, D. V., Ridley, D. A., Manktelow, P. T., Chipperfield, M. P., Pickering, S. J., and Johnson, C. E.: Description and evaluation of GLOMAP-mode: a modal global aerosol microphysics model for the UKCA composition-climate model, Geosci. Model Dev. Discuss., 3, 651-734, doi:10.5194/gmdd-3-651-2010, 2010.

Meng, Z. and Seinfeld, J.: Time scales to achieve atmospheric gasaerosol equilibrium for volatile species, Atmos. Environ., 30, 2889-2900, 1996.

Metzger, S. and Lelieveld, J.: Reformulating atmospheric aerosol thermodynamics and hygroscopic growth into fog, haze and clouds, Atmos. Chem. Phys., 7, 3163-3193, doi:10.5194/acp-73163-2007, 2007.

Metzger, S., Dentener, F., Krol, M., Jeuken, A., and Lelieveld, J.: Gas/aerosol partitioning 2. Global modeling results, J. Geophys.
Res.-Atmos., 107(D16), 4313, doi:10.1029/2001JD001103, 2002.

Metzger, S., Mihalopoulos, N., and Lelieveld, J.: Importance of mineral cations and organics in gas-aerosol partitioning of reactive nitrogen compounds: case study based on MINOS results, Atmos. Chem. Phys., 6, 2549-2567, doi:10.5194/acp-6-25492006, 2006.

Myhre, G., Grini, A., and Metzger, S.: Modelling of nitrate and ammonium-containing aerosols in presence of sea salt, Atmos. Chem. Phys., 6, 4809-4821, doi:10.5194/acp-6-4809-2006, 2006.

Nenes, A., Pandis, S. N., and Pilinis, C.: ISORROPIA: A new thermodynamic equilibrium model for multiphase multicomponent inorganic aerosols, Aquat. Geochem., 4, 123-152, 1998a.

Nenes, A., Pandis, S. N., and Pilinis, C.: Continued Development and Testing of a New Thermodynamic Aerosol Module for Urban and Regional Air Quality Models, Atmos. Environ., 33, 1553-1560, 1998b.

Pakkanen, T. A.: Study of formation of coarse particle nitrate aerosol, Atmos. Environ., 30, 2475-2482, doi:10.1016/13522310(95)00492-0, 1996.

Pye, H. O. T., Liao, H., Wu, S., Mickley, L. J., Jacob, D. J., Henze, D. K., and Seinfeld, J. H.: Effect of changes in climate and emissions on future sulfate-nitrate-ammonium aerosol levels in the United States, J. Geophys. Res.-Atmos., 114, D01205+, doi:10.1029/2008JD010701, 2009.

Rodriguez, M. A. and Dabdub, D.: IMAGES-SCAPE2: A modeling study of size- and chemically resolved aerosol thermodynamics in a global chemical transport model, J. Geophys. Res., 109, D02203, doi:10.1029/2003JD003639, 2004.

Roeckner, E., Brokopf, R., Esch, M., Giorgetta, M., Hagemann, S., Kornblueh, L., Manzini, E., Schlese, U., and Schulzweida, U.: Sensitivity of simulated climate to horizontal and vertical resolution in the ECHAM5 atmosphere model, J. Climate, 19, 3371-3791, doi:10.1175/JCLI3824.1, 2006.

Sander, R., Kerkweg, A., Jöckel, P., and Lelieveld, J.: Technical note: The new comprehensive atmospheric chemistry module MECCA, Atmos. Chem. Phys., 5, 445-450, doi:10.5194/acp-5445-2005, 2005.

Stier, P., Feichter, J., Kinne, S., Kloster, S., Vignati, E., Wilson, J., Ganzeveld, L., Tegen, I., Werner, M., Balkanski, Y., Schulz, M., Boucher, O., Minikin, A., and Petzold, A.: The aerosolclimate model ECHAM5-HAM, Atmos. Chem. Phys., 5, 11251156, doi:10.5194/acp-5-1125-2005, 2005.

Stier, P., Feichter, J., Roeckner, E., Kloster, S., and Esch, M.: The evolution of the global aerosol system in a transient climate simulation from 1860 to 2100, Atmos. Chem. Phys., 6, 3059-3076, doi:10.5194/acp-6-3059-2006, 2006.

Textor, C., Schulz, M., Guibert, S., Kinne, S., Balkanski, Y., Bauer, S., Berntsen, T., Berglen, T., Boucher, O., Chin, M., Dentener, F., Diehl, T., Easter, R., Feichter, H., Fillmore, D., Ghan, S., Ginoux, P., Gong, S., Grini, A., Hendricks, J., Horowitz, L., Huang, P., Isaksen, I., Iversen, I., Kloster, S., Koch, D., Kirkevåg, A., Kristjansson, J. E., Krol, M., Lauer, A., Lamarque, J. F., Liu, X., Montanaro, V., Myhre, G., Penner, J., Pitari, G., Reddy, S., Seland, Ø., Stier, P., Takemura, T., and Tie, X.: Analysis and quantification of the diversities of aerosol life cycles within AeroCom, Atmos. Chem. Phys., 6, 1777-1813, doi:10.5194/acp-61777-2006, 2006. 
Textor, C., Schulz, M., Guibert, S., Kinne, S., Balkanski, Y., Bauer, S., Berntsen, T., Berglen, T., Boucher, O., Chin, M., Dentener, F., Diehl, T., Feichter, J., Fillmore, D., Ginoux, P., Gong, S., Grini, A., Hendricks, J., Horowitz, L., Huang, P., Isaksen, I. S. A., Iversen, T., Kloster, S., Koch, D., Kirkevåg, A., Kristjansson, J. E., Krol, M., Lauer, A., Lamarque, J. F., Liu, X., Montanaro, V., Myhre, G., Penner, J. E., Pitari, G., Reddy, M. S., Seland, Ø., Stier, P., Takemura, T., and Tie, X.: The effect of harmonized emissions on aerosol properties in global models an AeroCom experiment, Atmos. Chem. Phys., 7, 4489-4501, doi:10.5194/acp-7-4489-2007, 2007.

Tost, H., Jöckel, P., Kerkweg, A., Sander, R., and Lelieveld, J.: Technical note: A new comprehensive SCAVenging submodel for global atmospheric chemistry modelling, Atmos. Chem. Phys., 6, 565-574, doi:10.5194/acp-6-565-2006, 2006 a.

Tost, H., Jöckel, P., and Lelieveld, J.: Influence of different convection parameterisations in a GCM, Atmos. Chem. Phys., 6, 54755493, doi:10.5194/acp-6-5475-2006, 2006b.

Tost, H., Jöckel, P., Kerkweg, A., Pozzer, A., Sander, R., and Lelieveld, J.: Global cloud and precipitation chemistry and wet deposition: tropospheric model simulations with ECHAM5/MESSy1, Atmos. Chem. Phys., 7, 2733-2757, doi:10.5194/acp-7-2733-2007, 2007a.

Tost, H., Jöckel, P., and Lelieveld, J.: Lightning and convection parameterisations - uncertainties in global modelling, Atmos. Chem. Phys., 7, 4553-4568, doi:10.5194/acp-7-4553-2007, $2007 b$.

Tost, H., Lawrence, M. G., Brühl, C., Jöckel, P., The GABRIEL Team, and The SCOUT-O3-DARWIN/ACTIVE Team: Uncertainties in atmospheric chemistry modelling due to convection parameterisations and subsequent scavenging, Atmos. Chem. Phys., 10, 1931-1951, doi:10.5194/acp-10-1931-2010, 2010.

Tsigaridis, K., Lathière, J., Kanakidou, M., and Hauglustaine, D. A.: Naturally driven variability in the global secondary organic aerosol over a decade, Atmos. Chem. Phys., 5, 1891-1904, doi:10.5194/acp-5-1891-2005, 2005.

Tsigaridis, K., Krol, M., Dentener, F. J., Balkanski, Y., Lathière, J., Metzger, S., Hauglustaine, D. A., and Kanakidou, M.: Change in global aerosol composition since preindustrial times, Atmos. Chem. Phys., 6, 5143-5162, doi:10.5194/acp-6-5143-2006, 2006.

Vandoren, J. M., Watson, L. R., Davidovits, P., Worsnop, D. R., Zahniser, M. S., and Kolb, C. E.: Temperature dependence of the uptake coefficients of nitric acid, hydrochloric acid and nitrogen oxide (N2O5) by water droplets, J. Phys. Chem., 94, p. 3265, 1990.
Veefkind, P.: Aerosol satellite remote sensing, Utrecht University, 1999.

Vehkamaki, H., Kulmala, M., Napari, I., Lehtinen, K., Timmreck, C., Noppel, M., and Laaksonen, A.: An improved parametrisation for sulfuric acid-water nucleation rates for tropospheric and stratospheric conditions, J. Geophys. Res.-Atmos., 107(D22), 4622, doi:10.1029/2002JD002184, 2002.

Vignati, E., Wilson, J., and Stier, P.: M7: An efficient size-resolved aerosol microphysics module for large-scale aerosol transport models, J. Geophys. Res., 109, D22202, doi:10.1029/2003JD004485, 2004.

Wexler, A. and Seinfeld, J. H.: Analysis of aerosol ammonium nitrate: Departures from equilibrium during SCAQS, Atmos. Environ., 26A, 579-591, 1992.

Wilson, J., Cuvelier, C., and Raes, F.: A modeling study of global mixed aerosol fields, J. Geophys. Res.-Atmos., 106(D24), 34081-34108, doi:2000JD000198, 2000.

Yeatman, S. G., Spokes, L. J., and Jickells, T. D.: Comparisons of coarse-mode aerosol nitrate and ammonium at two polluted coastal sites, Atmos. Environ., 35, 1321-1335, doi:10.1016/S1352-2310(00)00452-0, 2001.

Yu, S., Dennis, R., Roselle, S., Nenes, A., Walker, J., Eder, B., Schere, K., Swall, J., and Robarge, W.: An assessment of the ability of three-dimensional air quality models with current thermodynamic equilibrium models to predict aerosol $\mathrm{NO}_{3}^{-}$, J. Geophys. Res.-Atmos., 110, D07S13, doi:10.1029/2004JD004718, 2005.

Zhang, Q., Jimenez, J. L., Canagaratna, M. R., Allan, J. D., Coe, H., Ulbrich, I., Alfarra, M. R., Takami, A., Middlebrook, A. M., Sun, Y. L., Dzepina, K., Dunlea, E., Docherty, K., DeCarlo, P. F., Salcedo, D., Onasch, T., Jayne, J. T., Miyoshi, T., Shimono, A., Hatakeyama, S., Takegawa, N., Kondo, Y., Schneider, J., Drewnick, F., Borrmann, S., Weimer, S., Demerjian, K., Williams, P., Bower, K., Bahreini, R., Cottrell, L., Griffin, R. J., Rautiainen, J., Sun, J. Y., Zhang, Y. M., and Worsnop, D. R.: Ubiquity and dominance of oxygenated species in organic aerosols in anthropogenically-influenced Northern Hemisphere midlatitudes, Geophys. Res. Lett., 34, L13801+, doi:10.1029/2007GL029979, 2007.

Zhuang, H., Chan, C. K., Fang, M., and Wexler, A. S.: Formation of nitrate and non-sea-salt sulfate on coarse particles, Atmos. Environ., 33, 4223-4233, doi:10.1016/S1352-2310(99)00186-7, 1999. 